\title{
The Legacy of Bla ma dkar po: An Unsettled Dispute between Chone and Labrang on the Inner Asian Frontier
}

\author{
Gyatso Marnyi, Columbia University
}

Introduction

$\mathrm{M}$

do smad is a massive geographic region straddling Central Tibet and China proper. From the tenth century onward, the steppes, alpine meadows and valley alluviums nourished several powerful polities that took place through political, military and religious reconfigurations of hundreds of Tibetan tsho ba (group, clan or tribe). Historical accounts concerning such phenomenal powers are found rather scattered. Tibetan monastic narrative usually focuses on the history of eminent dharma and patron lineages instead of local political conflict and social change. Tibetan genealogical records construct idealized spiritual and secular lineages instead of reflecting the exercise of authority in reality. Chinese sources emphasize the Sino-centric political-cultural order on this frontier while paying little attention to the Tibetan management of community and the Tibetan principle of rulership on the ground. Hence, few available works in the academic literature on Mdo smad delve into the interactions between the coexisting regional polities and their respective control of tsho ba. However, a confrontation between the Chone Kingdom (1418-1950) and the regional authority centered in Labrang (1709-1950) showcases the complex politico-religious intercourse traversing tsho ba and the two polities' central administrations.

After decades of expansion, the religious influence of Labrang had infiltrated into Chone's jurisdictional borderland by the late nineteenth century. ${ }^{1}$ Although the two Tibetan powers abutted each other and maintained an amicable relationship, the death of a lama, who was born in the Chone-Labrang borderland and spectacularly ascended to power in Xinjiang, brought his hometown and the two regimes into an intricate contestation over his material and immaterial legacies. The dispute, which was concealed and reinterpreted by local Tibetan communities, was witnessed by several Gospel missionaries. Their accounts, in addition to diverse genres of historical document,

\footnotetext{
${ }^{1}$ For Labrang's expansion and the change of religious identity affiliation of tsho ba and their communal monasteries from Chone to Labrang, see Marnyi Gyatso, "Home on the Margins: Tsho ba Societies of the Chone Kingdom on the SinoTibetan Frontier, 1862-1952," PhD diss., (The Chinese University of Hong Kong, 2020), 139-51, 184-94.
} 
illuminate an inter-polity struggle for managing a federation and a monastery caught in-between Chone and Labrang, reveal the initiative of tsho ba against temporal and ecclesiastic authorities, and imply the social, political and religious rationales behind the scenario. This article draws attention to the dynamic relations between the politico-religious centers, namely Chone and Labrang, and the eighteen tsho ba in the lama's hometown. It examines how an influential religious authority came into being in local society, how the lay and religious rulers exerted control over a place, how the confrontation between Chone and Labrang was constrained in a covert and indirect way, and how tsho $b a$ as agents of social-political changes navigated themselves on the turbulent Sino-Tibetan frontier from the late Qing to early Republican period.

\section{Politico-Religious Structures of Chone and Labrang}

From the eighteenth century onward, Chone and Labrang were the most dominant Tibetan political-religious-trading centers in Mdo smad. The two regimes managed over 1,200 tsho ba that neighbored the diverse Han Chinese, Mongol and Hui Muslim groups in the borderland of today's Gansu, Qinghai and Sichuan. ${ }^{2}$ Although Chone Monastery (Ggon chen dga 'ldan bshad grub gling, Ch. Chanding si 禪 定寺) and Labrang Monastery (Gge ldan bshad sgrub dar rgyas bkra shis gyas su 'khyil ba'i gling) were considered institutional extensions of the Lhasa Dge lugs monastic universities, the Lhasa government had no control of the two religious institutions and local Tibetans. The hierarchical governmental structure in China proper also reached the limit here. Although Chone and Labrang fell under the nominal jurisdictions of Taozhou 洮州 and Xunhua 循化 subprefectures (Ch. ting 廳), which were respectively administered by Lanzhou 蘭州 and Xining 西寧 prefectures (Ch. $f u$ 府), the Chinese administration staffed by circulated officials (Ch. linguan 流官) was never established in either places before the late 1920s. ${ }^{3}$ The Qing and Republican political influences became even weaker westward. For centuries the region was

2 Ma Dengkun and Wanma Duoji, Kan lho'i bod kyi tsho shog lo rgyus mdor bsdus (Hezuo: Gannan baoshe, 1994).

3 Tibetan settlements ruled by the Chone kings were under the nominal jurisdiction of Taozhou Garrison 洮州衛 (Sub-prefecture since 1748) from 1418 onward. Tibetan groups in the realm of Labrang were managed by Hezhou 河州 (presentday Linxia 臨夏) in name only. In 1762, the Qing set up Xunhua Subprefecture to govern this region as it was too far away from Hezhou. From 1823, Xunhua was subordinated to Xining. Zhang Yandu, Taozhou tingzhi (Taipei: Chengwen chubanshe, 1970), 838, 842. Gong Jinghan, Xunbua tingzhi (Taipei: Chengwen chubanshe, 1968), $20-1$. 
governed by local Tibetan lay and religious authorities with various titles. $^{4}$

Undeniably, the official recognitions from Lhasa and Beijing were crucial for frontier rulers to accumulate politico-religious capital. It is also noteworthy that secular and ecclesiastic powers were often associated with each other and not strictly distinguished by Tibetans. ${ }^{5}$ Both regimes promoted the centralized Dge lugs monastic education, institutionalized the hierarchical relation between central and communal monasteries with the prime-subordinate/mother-son monastic system ( $m a$ bu dgon gyi 'brel ba), and constructed the charismatic lineage to consolidate temporal and spiritual rule. Hence, Chone and Labrang are typically considered theocracies (chos srid zung 'bre) differing only in that Chone's secular power outshined its religious authority, while Labrang's religious power was absolutely dominant. ${ }^{6}$ This observative assessment, however, is quite overgeneralized. As this article will illustrate, the nature of the power held by the Chone and Labrang ruling lineages, respectively, differed in nature. They rose to power in disparate circumstances and set up dissimilar political infrastructures. Even though Buddhism was inseparable from the formation of local authorities, monastic leaders possessed varying political statuses and worked with lay officials differently. In contrast to what has been identified by Yudru Tsomu as the three categories of Kham polities, namely, the merging of religion with politics, the alliance between secular and religious powers, and the share of authority by secular ruler and monastic institution, Chone and Labrang offer two additional types of political structures in the eastern Tibetan Plateau. ${ }^{7}$

\footnotetext{
${ }^{4}$ The titles include rgyal po, dpon po, dgon po, sa skyong, nang so, mkhan chen, mkhan po and bla dpon in Tibetan, and zhibuishi 指揮使, zhihui qianshi 指揮薟事, tusi 土司, tuguan 土官, qianhu 千戶, baibu 百戶, dugang 都綱, senggang 僧綱 and sengzheng 僧正 in Chinese. See Gray Tuttle, "Pattern Recognition: Tracking the Spread of the Incarnation Institution through Time and across Tibetan Territory," Revue d'Etudes Tibétaines, 38 (2017): 29-64; “An Overview of Amdo (Northeastern Tibet) Historical Polities."

5 Joseph Fletcher suggested that "religion in Tibetan eyes was not clearly distinguishable from political allegiances." Based on this point, Paul Nietupski elaborates how the Qing-Labrang relation was perceived by Tibetans. See Labrang Monastery: A Tibetan Buddhist Community on the Inner Asian Borderlands, 1709-1958 (Lanham, Md.: Lexington Books, 2011), xvi-xvii.

6 Yang Shihong, Zhuoni Yang tusi zhbuanlüe (Chengdu: Sichuan minzu chubanshe, 1989), 1.

7 Yudru Tsomu categorizes the Kham political systems into three precise types whereby the ultimate power respectively lay in the hands of a religious leader, secular ruler, or both. See The Rise of Gönpo Namgyel in Kham: The Blind Warrior of Nyarong (New York, London: Lexington Books, 2015), 8-9.
} 
By obtaining ratification from the Ming-Qing emperors, sponsoring eminent lamas, expanding Chone Monastery and founding the Chone mkhan po lineage, the Chone kings (mgon po/rgyalpo) or Yang chieftains (Ch. Yang tusi 楊土司) steadily ascended to power in the Klu chu (Ch. Taohe 洮河) and 'Brug chu (Ch. Bailongjiang 白龍江) valleys. From the 1680 s, they superposed a central political structure upon a layer of local authorities and exerted control over six hundred tsho ba in the present-day southern Gansu. This system had a secular government comprising the yongs 'dus Palace, also known as Chone chieftain yamen (Ch. tusi yamen 土司衙門), twelve inner base-villages (nang grangs ka bou gnyis), four outer base-villages (phyi grangs ka bzhi) and forty-eight banners (dmag ru, Ch. qi 旗). The royal lineage's estates were concentrated in the base-villages. A banner comprised six to twentyfive settlements known by locals as village ( $s d e b a)$ or tsho $b a$. It consisted of one, two or three sub-units. Local Tibetans used different names, which combined khag, tsho ba or sde ba with number, to call their sub-units. ${ }^{8}$ In addition, the lay power was secured by a religious administration constituted of the Senggang yamen (lhag gi nang), ParishAssembly Office (spyi khang, Ch. shangshulou 尚書樓) and estates (nang chen or bla brang) of eighteen reincarnations (sprul sku) in Chone Monastery. The abbot or mkhan po position at the apex of the religious administration was held by either the king or his younger brother who utterly appointed the dharma throne holders (khri pa) to communal monasteries. The abbot managed four colleges (grwa tshang), seventeen religiously affiliated communities (chos sde), fifty-four son/subordinate monasteries (bu dgon) and several dozens of hermitages (ri khrod). This political structure is characterized as the merging of politics with religion in which the royal family held the ultimate secular power and relatively dynamic authority in the religious domain. It had a centralized secular government and a loose religious administration, supervising and working with tsho ba leaders.

\footnotetext{
${ }^{8}$ Each banner roughly coincides, in terms of its population and territory, with what are today recognized as town (Ch. xiang).

${ }^{9}$ Brag dgon pa dkon mchog bstan pa rab rgyas, Mdo smad chos 'byung (Lanzhou, Kan su'u mi rigs dpe skrun khang, 1982), 660-66; Ma and Wanma, Kan lho'i bod kyi tsho shog lo rgyus mdor bsdus, 265-314. For a description of Chone's politico-religious system, see Marnyi Gyatso, "Home on the Margins," 81-95.
} 


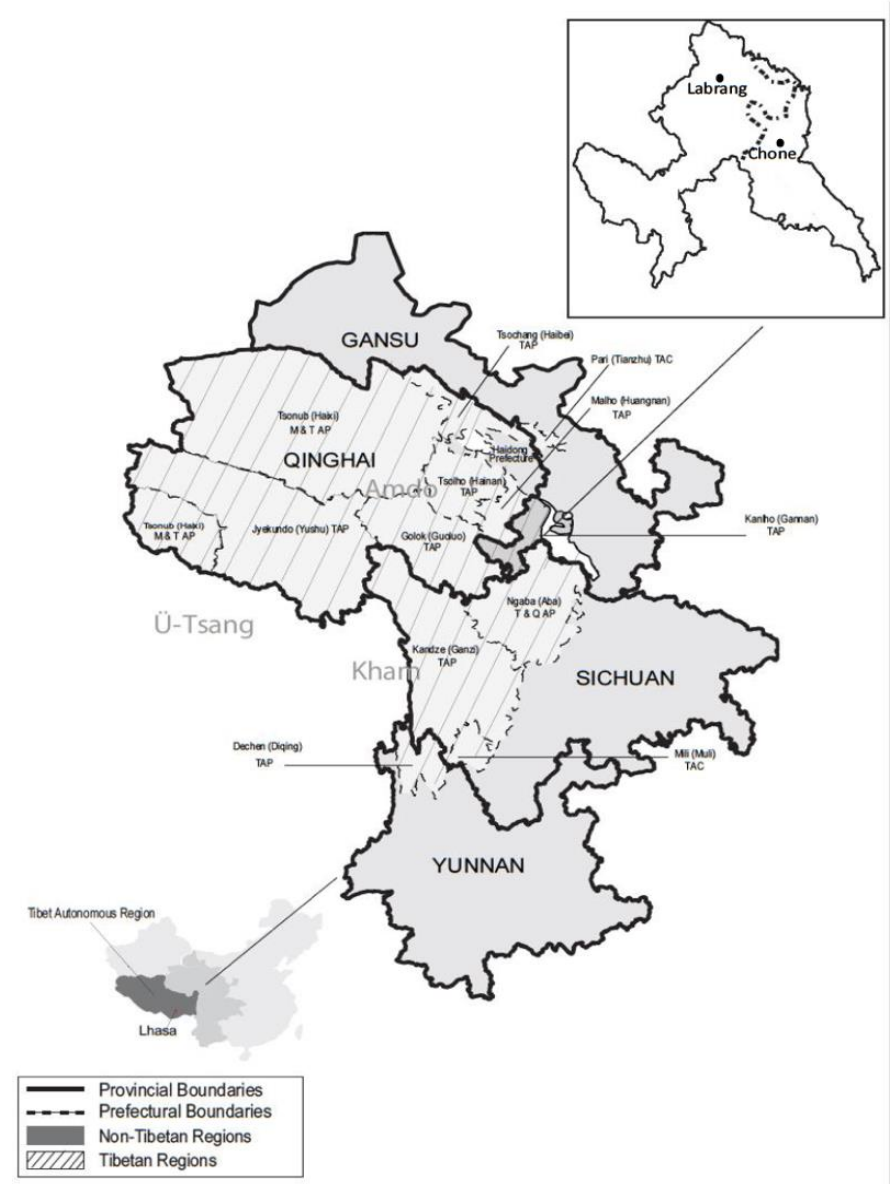

Map 1. Chone and Labrang in Cultural Tibet

In Labrang, the reincarnation lineage of the 'Jam dbyangs bzhad pa received recognition from the Dalai and Panchen lamas and gained political and financial support from the Manchu emperors. With the patronage of Henan Mongol princes and Tibetan local chiefs, the First 'Jam dbyangs bzhad pa rdo rje (1642-1721) built a monastery on the northern bank of the Bsang chu River (Ch. Daxiahe 大夏河). A monastic bureaucracy on the model of monastic universities in Lhasa was adopted at the outset for the purpose of internal governance. From the mid-eighteenth century on, the 'Jam dbyangs lineage allied with hundreds of tsho ba between the Dgu chu (Ch. Longwuhe) valley and northern Rnga ba (Ch. Aba 阿垻) grassland, forming a religious realm with over a hundred subordinate monasteries and thirty reincarnations' estates. According to Paul Nietupski and others' investigation, these tsho $b a$, which formed villages or larger federative units/military alliances (shog pa or shog kha, nomadic in most cases), 
were arranged into divine communities (lha sde), human communities ( $m i$ sde) and religiously affiliated communities based on their relations with Labrang Monastery. The religious, political and military affairs of a divine community were managed by a Labrang-appointed administrator (sku tshab). A human community usually had its own lay or religious leader, and managed local affairs without direct interference of Labrang. The community occasionally donated money and goods to Labrang. For a religiously affiliated community, its communal monastery was often a subordinate/son institute of Labrang, the prime/mother monastery (ma dgon) that supervised local monastic education and religious affairs. ${ }^{10} \mathrm{Up}$ to the $1890 \mathrm{~s}$, the monastic bureaucracy had evolved into a complex administrative body that managed the monastery's estates, arranged regional Buddhist education, designated dharma throne holders, maintained reincarnation lineages and exercise authority over lay people. Labrang's political system was based on the alliance between local secular and religious powers, which was supervised by the 'Jam dbyangs bzhad pa. It was an ecclesiastic polity resembling a mandala structure. ${ }^{11}$

Speaking of the governmental systems, Chone and Labrang had few similarities. The Chone king inherited his official title and held a military position in the Qing bureaucracy. The yongs 'dus Palace was designed like a Chinese sub-prefectural yamen. The bureaucratic apparatus consisted of the secretariat, revenue and administrative departments that were respectively in charge of 1) advisory and clerical works, 2) revenue management, 3) and tax collection, militia conscription and judicial issue. The advisor (Ch. shiye 師爺), the head of the secretariat department, was a reputable Chinese intellectual from a near county. He and his clerks were responsible for drafting official documents. The revenue department was staffed by the superior manager (Ch. da zongguan 大總管), second manager or treasurer (Ch. er zongguan 二總管) and third manager or chamberlain (Ch. san zongguan 三總管). They decided issues concerning fiscal, trade and the royal revenue. Employees in the administrative department were in five ranks. A superior headman (Ch. da toumu 大頭目) and a vice superior headman (Ch. fu toumu 副頭目) in the highest two ranks took charge of most administrative and judicial issues in the kingdom. The thirdrank official was a chief messenger (Ch. chuanhao toumu 傳號頭目) who

\footnotetext{
10 Here I borrow Nietupski's translation of the terms used in Labrang. Labrang Monastery, 66-80. Ma and Wanma, Kan lho'i bod kyi tsho shog lo rgyus mdor bsdus, 165264. Li Anzhai, History of Tibetan Religion: A Study in the Field, translated by Chie Nakane (Tokyo: The University of Tokyo, 1982), 8-16.

$11 \mathrm{Ma}$ and Wanma, Kan lho'i bod kyi tsho shog lo rgyus mdor bsdus, 165-264. For considering Tibet as a "galactic polity," a metaphoric description of polity that resembles mandala structure, see Geoffrey Samuel, Civilized Shamans: Buddhism in Tibetan Societies (Washington and London: Smithsonian Institution Press, 1993), 62.
} 
supervised three messengers to deliver messages, collect information and issue orders on behalf of the king, and administered two wardens (Ch. bantou 班頭) to manage the yamen prison with ten jailers (Ch. banyi 班役). The fourth-rank officials consisted of thirty-two accountants (grangs shes). They were also called banner-chiefs (Ch. qi ¿ hang 旗長) and had the power to handle taxation, lawsuit and militia affairs for the forty-eight banners. The sixteen minor headmen (Ch. xiaotou 小頭) of base-villages were the fifth-rank officials. They dealt with communal affairs and assisted the five branches of royal lineage to run estates in the base-villages. All Tibetan officials were selected by the king from capable men of the twelve inner-base villages. In addition, there were seventy-two local managers (tsung gon, Ch. zongguan 總管), who were originally local leaders and recognized by the king, worked for banner-chiefs to manage affairs of the seventy-two subunits in the forty-eight banners. Local managers, who did not receive any forms of salary from the king, were regarded as local representatives instead of yamen officials. ${ }^{12}$

The situation was more complicated in Labrang, as Li Anzhai, Ma Dengkun, Wanma Duoji and Paul Nietupski illustrate in detail, the political structures were dynamic and full of local variations across the expanding ecclesiastic realm of the 'Jam dbyangs lineage. Labrang exerted power in cases of religious affair, legal disputation, tax collection, corvée levying and militia enlistment primarily through the Central Office (yig tshang) of the aforementioned complex administrative body. The main estate of the 'Jam dbyangs was managed by his chief attendant (sku bcar mkhan po), treasure (phyag mdzod), internal affairs manager (nang mdzod) and tutor (yongs 'd zin). Under them were the representatives (sku tshab) nominated from the eighty monkattendants (zhabs phyl) and assigned for three-year to manage divine communities. In addition, reincarnate lamas at Labrang were arranged into four ranks based on their achievements and influences. They were known as golden throne reincarnations (gser khr $)$, teacher/vows-giver reincarnations (mkban po), abbot reincarnations (dgon bdag bla ma) and normal reincarnations (sprul sku). With few exceptions, they owned estates (nang chen) at Labrang and properties elsewhere. According to the monastic regulation, these estates were managed by varying numbers of attendant of the sprul sku without any interference by the main estate. In each divine community, the representative assigned by

12 Although messengers were likely unranked officials, they were considered more powerful than banner-chiefs by local people. The forty-eight banners were "eighteen banners within the pass" ('og sgang mar nang dmag ru bcu brgyad), "twelve banners beyond the pass" ('og sgang mar nang dmag ru bcu gnyis), "Brug chu four banners" (rol bad mag ru bzhi), "Upper The bo six banners" (the bo stod ma dmag ru drug) and "Lower The bo eight banners" (the bo smad ma dmag ru brgyad). See Zhuoni wenshi ziliao, vol.1, 4-6; vol.3, 32-5; Zhang Yandu, Taozhou tingzhi, 273, 943-51. 
Labrang managed most communal affairs for three years. In human communities, tsho ba were the noncompulsory sponsors of Labrang and its lamas. Local secular authorities held substantial power. Labrang might ratify hereditary headmen or gowa ('go pa or 'go ba) in human communities but did not appoint representatives to directly handle local affairs. The religiously affiliated communities sent local reincarnations and monks to study at Labrang and accepted the throne holders assigned by the 'Jam dbyangs. ${ }^{13}$

Apart from the central administrations, the mandala-like structures of local politico-religious authorities were identical in Chone and Labrang. On the one hand, for the physical distances between the central administration and different $t$ sho $b a$, the direct and systematic control was largely restrained within a day's horse-riding radius. Tsho $b a$ in this category were the base-villages of Chone or divine communities of Labrang. They were bonded to the lay or monastic estates. On the other hand, in areas reckoned as a three-day to oneweek horse-riding trip, local leaders and communal councils either managed their tsho ba independently, or cooperated with expatriate officials such as Chone banner-chiefs and Labrang representatives. Local leaders obtained power through inheritance, election and selection. They were either nobles, hereditary leaders, elected prestigious figures or appointed and served in rotation. Normally, the mandala-like structure of authorities consisted of chiefs (dbon po) and minor chiefs (dbon phran, nomadic gur gang bo and sedentary ming btags) of tsho ba, religious mediators and lords (mgon po) of larger units, elder (rgan po) councils of temporary or fixed federative units such as shog pa and shog kha, as well as leaders of seasonal organizations like the encampment-circle (ru skor) and mutually obligated communal helping (u lag) group. They practically coped with various local matters. ${ }^{14}$

\section{Tsho ba and Regional Rulers}

Systematic research on tsho ba is scarce in comparison with its significance to understand Mdo smad Tibetan societies. Limited historical references and ethnographic data obstructs contemporary scholars from precisely examining this organization. The scattered

13 Nietupski, Labrang Monastery, 60-70. Ma and Wanma, Kan lho'i bod kyi tsho shog lo rgyus mdor bsdus, 165-264. Li Anzhai, History of Tibetan Religion, 35-42. For the detailed account of the reincarnation lineages at Labrang Monastery, see Zha zha, Labulengsi buofo shixi (Lanzhou: Gansu minzu chubanshe, 2000).

14 Based on field research in Taozhou and near Amdo Tibetan areas during 19231927 and 1929-1935, the pioneering missionary anthropologist Robert Ekvall depicted the social organizations and political structures of the Tibetan communities in the Gansu-Amdo borderland during the 1920s and early 1930s in detail. See Cultural Relations on the Kansu-Tibetan Border (Chicago: University of Chicago Press, 1939), 4-82. For a survey on Amdo nomadic social organization, see Matthias Hermanns, Die Nomaden von Tibet (Wien: Verlag Herold, 1949), 231. 
accounts up to date depict an oversimplified, idealized and inconsistent picture of tsho ba. What is tsho ba? When non-Tibetan anthropologists and historians raise this question, their informants often give descriptive answers mixing with the origin legends, migration histories and functions of tsho $b a$. These responses corroborate neither premodern Tibetan accounts nor historical works produced in the twentieth century. It is not easy to find written records showing that tsho ba comprised related patriarchal/matriarchal lineages, or households shared same founding ancestor. Few ethnographic data conform to the Tibetan conclusion that tsho $b a$ is clan and the membership is primarily assigned through kinship.

In general, historians and anthropologists translate tsho ba loosely as lineage and clan, or cautiously as political unit, social group and territorial division. ${ }^{15}$ As some scholars notice that the Tibetan communitarian base of territory and practices of intimate relation in Mdo smad resemble a tribal society, they regard tsho ba as tribe. ${ }^{16}$ Since

15 For a review of the different translations of the term "tsho $b a$," see Reinier Langelaar, "Descent and Houses in Rebgong (Reb gong): Group Formation and Rules of Recruitment among Eastern Tibetan tsho ba," in Mapping Amdo: Dynamics of Change, edited by Jarmila Ptáčková and Adrian Zens (Prague: Oriental Institute CAS, 2017), 155-83; "Historical and Social Organisation on the Eastern Tibetan Plateau: The Territorial Origins and Etymology of tsho-ba," Inner Asia 21 (2019): 8. For accounts on tsho ba as descent-based groups, see Katia Buffetrille, "Some Remarks on Mediums: The Case of the lha pa of the Musical Festival (Glu rol) of Sog ru (A mdo)," Mongolo-Tibetica Pragensia 1, no.2 (2008): 15-6; Samten Karmay, "The Social Organization of Ling and the Term phu nu in the Gesar Epic," Bulletin of the School of Oriental and African Studies 58, no.2 (1995): 303. Emily Yeh, "Tibetan Range Wars: Spatial Politics and Authority on the Grasslands of Amdo," Development and Change 34, no.3 (2003): 510. For considering tsho ba as clan, see Robert Ekvall, Cultural Relations on the Kansu-Tibetan Border (Chicago: University of Chicago Press, 1939), 79. For studies regard tsho ba as social groups and territorial units, see Graham Clarke, "Aspects of the Social Organisation of Tibetan Pastoral Communities," in Tibetan Studies, Proceedings of the $5^{\text {th }}$ Seminar of the International Association of Tibetan Studies, Narita 1989, (Narita, Japan, 1992), 399; Stobs stag lha, "A Multi-Ethnic Village in Northeast Tibet: History, Ritual, and Daily Life in Chu cha," Asian Highlands Perspectives 24 (2013): 33. Marie-Paule Hille, Bianca Horlemann and Paul Nietupski suggest that more detailed local ethnographic research needs to be done instead of simply translating the term. See Muslims in Amdo Tibetan Society: Multidisciplinary Approaches (Lanham: Lexington Books, 2015), 4-5.

16 For studies that generally treat tsho ba as tribe, see Fernanda Pirie, "Feuding, Mediation and the Negotiation of Authority among the Nomads of Eastern Tibet," Max Planck Institute for Social Anthropology Working Paper 72 (2005): 10. Lawrence Epstein and Peng Wenbin, "Ritual, Ethnicity and Generational Identity," in Buddhism in Contemporary Tibet: Religious Revival and Cultural Identity, edited by Melvyn Goldstein and Matthew Kapstein (Berkeley: University of California Press, 1998), 120-138. Nancy Levine, "From Nomads to Ranchers: Managing Pasture Among Ethnic Tibetans in Sichuan," in Development, Society, and Environment in Tibet. Papers Presented at a Panel of the 7th Seminar of the International Association for Tibetan Studies, Graz 1995, edited by Graham Clarke (Vienna: Verlag der Österreichischen Akademie der Wissenschaften, 1998), 69-76. 
the twentieth century, Chinese scholars under the influences of social Darwinism and Marxism replaced the terms clan (Ch. $z u$ 族) and federation (Ch. bu 部) with tribe (Ch. buluo 部落). The term connotes a strong sense of primitiveness and backwardness in the Chinese ethnopolitical context. Some Tibetan scholars in China also use "buluo" to translate tsho ba, tsho shog and tsho khag. ${ }^{17}$ In addition, Langelaar employs Lévi-Strauss' concept of "house society" (société à maisons) to analyze the internal structures and relations of Reb gong Tibetan tsho $b a$. Focusing on household (khang), the most basic social unit, Langelaar demonstrates that $t s h o b a$ is social networks overarching households. ${ }^{18}$ In short, the overall academic debate is about the presentation of tsho ba as a unilineal descent-based unit, territorially defined unit or village intra-network centered unit.

Based on my fieldwork in Kan lho (Gannan) Tibetan Autonomous Prefecture, it seems that unilineal descent group(s) formed the base of tsho ba. A tsho ba consisted of several to around thirty households (tentholds in nomadic area). The households identified themselves as being descended from a legendary ancestor or brothers serving as frontier soldiers of the Tibetan Empire. Aside from such fictious kinship, within a tsho $b a$, there is a full category of terms for inter-household relation to explain Tibetan epistemologies of inclusion and exclusion. It is evident for all members that agnatic sibling (sha nye, sha khrag, spun mched and gnyen nye) and reciprocal assistant $(u$ lag) relations among households played a crucial role in forming sub-tsho ba organization-group of related houses (tshang). The subgroup was critical for related households to organize agricultural or pastoral production. Households of a subgroup usually shared the same bone-lineage (rus pa) and bore the same lineage name (rus ming). They worshipped the same protector deity (srung lha) and the same mountain gods ( $y u l$ lha). The lineage origin, mostly idealized, is typically traced back to the oldest four/six ancestral clans and their branches as referenced in Tibetan imperial histories from the seventh to ninth centuries. Keeping these mundane and divine relations alive was extremely important to define tsho ba membership. ${ }^{19}$ Through

17 See Chen Qingying ed., Zangzu buluo z̧hidu yanjï (Beijing: Zhongguo zangxue chubanshe, 2002), 1-21. For a brief comment on the Chinese translation of tsho ba, see Marnyi Gyatso, "Home on the Margins," 29-36. The two well-known books about tsho ba in Mdo smad and particularly Kan lho by Zhouta ('Brug thar) are mainly based on the accounts of Ma Dengkun and Wanma Duoji. The authors also consider Tibetan local communities as tribes. See Zhouta, Mdo smad Rma khug tsha 'gram rong 'brog yul gru'i sngon byung mes po'i ngag gi lo rgyus deb ther chen mo zhes bya ba bzhugs so (Pe cing: Mi rigs dpe skrun khang, 2005); Gannan zangzu buluo shehui lishi yu wenhua yanjiu (Beijing: Zhongguo zangxue chubanshe, 2013).

18 Langelaar, "Descent and Houses in Rebgong (Reb gong)," 156-79. Claude LéviStrauss, The Way of the Masks (Seattle: University of Washington Press, 1982), 17374.

19 Marnyi Gyatso, "Home on the Margins," 63-80. For studies examining the rus, see Jonathan Samuels, “Are We Legend? Reconsidering Clan in Tibet," Revue d'Etudes 
kinship, marriage, religion, political alliance and other strategies for resource management and self-preservation, subgroups were overarched by the tsho $b a$. When it comes to inter-tsho $b a$ feuds, political matters and religious affairs, $t$ sho $b a$ served as a basic organization. In the moment of a regional war, the shog pa of several tsho ba became a basic fighting unit. ${ }^{20}$

Although territoriality was significant for $t$ sho $b a$, the relationship between tsho $b a$ and territory was not unalterable. Social unrest and natural catastrophe oftentimes disturbed the stability of the tie between tsho ba and land. A tsho ba could move to a new place, recruit new households and even restructure (merging or dividing) itself after conquering adjacent tsho ba or being defeated in feud. This practice of changing alliance from one tsho $b a$ or shog pa to another also applied to subgroup and single household. Turbulent nature of the Sino-TibetanMuslim-Mongol frontier led to the fluid relation between tsho ba and land. As Hans Stübel found in Dme bo, which was common across Mdo smad, "often a certain family strives to shift from a less influential group to a more influential one; they can do this by presenting the group leader and several respected members of the group with a sheep and several chin (jin 斤) of wine and inviting them to a meal." ${ }^{21}$ In general, tsho $b a$ in agricultural area was more stable than those in pastoral area. External causes such as a regional ruler's suppression, Mongol invasion, Manchu incorporation, Tibetan-Muslim conflict and Chinese integration all triggered territorial changes and internal reconfigurations of tsho ba in Mdo smad. Territory was defined by not only the practical management of land, water, forest and pasture, but also the relations with territorial deities who were relevant to the communal good. Consequently, reserving the average number of households and maintaining diverse relations with the immaterial

Tibétaines 37 (2016), 293-314. Nancy Levine, "The Theory of Rü Kinship, Descent and Status in a Tibetan Society," in Asian Highland Societies in Anthropological Perspective, edited by Christoph von Fürer-Haimendorf (New Delhi: Sterling Publishers, 1981), 52-78.

${ }^{20}$ For how the small units were organized into tsho $b a$ or lager alliance in Rma lho and Songpan, see Dpal ldan bkra shis and Kevin Stuart, "Perilous Novelties: The Amdo Tibetan Klu-rol Festival in Gling-rgyal Village," Anthropos 93 (1998): 38-40; Kang Xiaofei and Donald S. Sutton, Contesting the Yellow Dragon: Ethnicity, Religion, and the State in the Sino-Tibetan Borderland (Leiden, Boston: Brill, 2016), 25-6. Jack Patrick Hayes, A Change in Worlds on the Sino-Tibetan Borderlands: Politics, Economies, and Environments in Northern Sichuan (Lanham: Lexington Books, 2014), 22-3, 37-8. Emily Yeh notices that there are clans overarching tsho ba. See "Tibetan Range Wars," 510.

${ }^{21}$ Hans Stübel, The Mewn Fantzu: A Tibetan Tribe of Kansu (New Haven: HRAF Press, 1958), 56. For a similar account on Rma chu and Mgo log Tibetans, see Fernanda Pirie, "Feuding, Mediation and the Negotiation of Authority among the Nomads of Eastern Tibet," 12. 
world were crucial for a tsho ba to bond with new land and reestablish territoriality after relocation. ${ }^{22}$

The notion that territory belonging to a regional ruler such as the Chone king or the 'Jam dbyangs bzhad pa, which was an assumption of Chinese frontier officials and gazetteer compilers, was uncommon among Tibetans. Similar to other Tibetan frontier polities, the political sway of Chone and Labrang was defined by a center instead of a fixed border. Spatial distance and mountainous topology were the major obstacles for the development of systematic and centralized control. The power of a ruler was based on his governance of, or broadly speaking, relationship with tsho ba rather than the size of territory. The ruler's influence on the number of tsho ba was pivotal to determine the scale of his realm. ${ }^{23}$ To be specific, the relation between regional politico-religious center and tsho ba in Chone and Labrang was usually fourfold. First, tsho ba accepted the control of a regional ruler to receive military or political protection against Mongol raiders and other Tibetan marauders, as well as ward off Manchu, Chinese and Muslim integrations. Second, tsho ba joined the Chone banner system/Labrang alliance to benefit from trade that was managed by the ruler. Market activity was organized outside Chone and Labrang monasteries, Tibetans also combined trade with religious purposes. Third, tsho ba often forged ties with the ruler through patronizing a prestigious lama and branch monastery to fulfill the pragmatic and karma-oriented needs of rituals. Fourth, some tsho ba were absorbed into the regional polity through military conquest. The establishment of these relations were on the basis of Tibetan social, political and religious norms, historical precedents and local practices. Both regional rulers and tsho $b a$ acknowledged certain rules. Leaving communal affairs in the hands of tsho ba leaders and elder councils was the principal base for regional authorities to exercise rulership. With the exception of large-scale range wars, open challenge to Chone/Labrang regime or revolts against Manchu-Chinese authorities, the regional rulers would not directly meddle in tsho ba matters. Even in extreme cases, the highest rulers more often than not were mediators instead of arbitrators. ${ }^{24}$

22 For specific cases, see Marnyi Gyatso, "Home on the Margins," chapter 2-4.

${ }^{23}$ Many early twentieth century travelers noticed this situation. See Ekvall, Cultural Relations on the Kansu-Tibetan Border, Joseph Rock, "The Amney Ma-Chen Range and Adjacent Regions: A Monographic Study," in IsMEO 12 (1956); Reginald Farrer, On the Eaves of the World (London: Edward Arnold, 1916), vol.1, 164; Eric Teichman, Travels of a Consular Officer in North-West China (Cambridge: Cambridge University Press, 1921), 134.

${ }^{24}$ This is elaborated in my dissertation. See Marnyi Gyatso, "Home on the Margins," 68-100. For the Qinghai Mongols' influence on Mdo smad, see Marnyi Gyatso, "The Ming, Tibetan and Mongol Interactions in Shaping the Ming Fortification, Multicultural Society and Natural Landscape in Mdo smad, 1368-1644." In Revue d'Etudes Tibétaines 55 (2020): 371-74. For an analysis of Tibetans' different needs of rituals, see Samuel, Civilized Shamans, 177-212. 
The relation of regional ruler and $t s h o b a$ was conditioned by the long self-ruled character of tsho ba and federative units in Mdo smad. Since households of a tsho ba had more or less equal social, economic and political status, in spite of the regional variations, the ruler had to pay attention to the self-managing power of tsho $b a$ members as a whole. The collective will and action of a tsho ba or federative unit were not neglectable. Serious conflict between local alliance and regional ruler was not rare. Thus, the ruler-tsho ba relation was not necessarily unilateral and dominated by regional ruler. A tsho ba could separate itself from a military alliance, political federation, religious sovereign and kingdom according to the traditional norm and communal decision. ${ }^{25}$ To sum up, tsho ba was the basic Tibetan social, religious, political, economic and territorial organization in Mdo smad. It affected the formation of societal structure, political system and local politics on the Tibetan frontier. It was a non-negligible agent of local social and political change.

\section{The Rise of Bla ma dkar po Kun dga' rgyal mtshan}

Bla ma dkar po Kun dga' rgyal mtshan (1835-95) was born into a household of Zhing khams, one of the eighteen tsho ba along Chas pa valley (Chas dpal zhing or Chab bu gshis, Ch. Chebagou 車巴溝/ 扯霸溝) in the northwestern corner of the Chone Kingdom. The eighteen tsho ba constituted two semi-pastoral federative units: Ya 'gag and $\mathrm{Ma}$ 'gag. ${ }^{26}$ Like elsewhere in Mdo smad, such units co-organized militias in moments of crisis and collaborated to tackle religious affairs. Meanwhile, inter-tsho ba friction was quite common. Around the 1700s, the eleventh Chone ruler Dmag zor mgon po (Yang Rusong 楊汝松, b. 1686) incorporated these tsho ba into Chone and organized them into one of the forty-eight banners. Chas pa Tibetans became the king's subjects (mi ser, Ch. baixing 百姓). In Kun dga' rgyal mtshan gyi rnam thar, the hagiography of Bla ma dkar po justified by Tibetan Buddhist values, the author Skal bzang legs bshad indicates that Bla ma dkar po's parents, who were devout Dge lugs pa followers, sent him to Chone Monastery in 1843. A local tale suggests that he ran away from his home after injuring a neighbor's yak with a spear. As the case was implicated in a three-year feud, he hid at Yid dga' chos gling Hermitage to avoid punishment. Afterwards, he became a disciple of Dge shes

25 Kang and Sutton, Contesting the Yellow Dragon, 25. Pirie, "Feuding, Mediation and the Negotiation of Authority among the Nomads of Eastern Tibet," 12. Stübel, The Mewu Fantzu, 56.

26 The eighteen tsho ba were Brgya chad, Rme ru nin pa, Rme ru srib pa, Dga' tshang, Ske rgas and Yul dza tshe in Ya 'gag unit, and Dgon pa, Rgod tsang, Zhing khams, Gong gcod, Brag rtsa, Mra rtsa, Lung mdo, Mdo khog, Bya bug, Phan khyim, A rgyu nang and Stag 'gag in Ma 'gag unit. 
Ngag dbang bstan 'dzin and received elementary monastic training at the hermitage. ${ }^{27}$

At that time, Chone Monastery's Eighty-eighth khri pa Mkhyen rab bstan pa, who was later recognized as the First Dbyi li tshang, established the patron-priest relation with Oirats Mongols in Dzungaria 準噶爾, or Lower Mongol (smad phyogs sog yul). He made routine trips to preach and collect donations in northwestern Xinjiang (Lower Mongol). In 1847, Bla ma dkar po was selected as an attendant to the aged Dbyi li tshang and to visit Hoboksar (Ch. Huobokesaili 霍 博克賽里). In contrast to the time-consuming trip, his stay in Lower Mongol was brief. He returned to Chone and started to learn Tibetan medicine and healing rituals. ${ }^{28}$ At this point, the Second Tshe smon gling ho thog thu 呼圖克圖 Ngag dbang 'jam dpal tshul khrims rgya mtsho (1792-1860), who was then serving as the Seventy-first Dga' ldan khri pa and the regent of Tibet, was deposed from all of his positions by the Daoguang 道光 Emperor (1782-1850). He was ordered to spend the rest of his life under surveillance in Chone. ${ }^{29} \mathrm{Bla}$ ma dkar po did not have any meaningful contact with the Second Tshe smon gling yet. In 1852, he embarked on the long journey again and travelled extensively in today's Ili 伊犁 and Altai 阿爾泰. He received abundant alms from two Uriankhai 烏梁海 Mongol banners and became known for magical rituals and efficacious Avalokiteshvara pills (mani rilbu). The healing skills brought him great fame after he stemmed the plague in Tarbagatai (Ch. Tacheng 塔城), the treaty port opened for Russia at the western edge of Qing China. The local jasagh (Ch. zhasake 扎薩克) became his sponsor and Mongols referred to him as the "White Master" (Tsha gan dge rgan). However, because of the

27 Based on Rje btsun byams pa mthu stobs kun dga' rgyal mtshan gyi rnam thar, Lobsang Yongdan gives a detailed chronological description on his life experience and the invention of a new reincarnation lineage by war. Here I use, in addition to the hagiographic account, Qing official documents and various local records to supplement Lobsang Yongdan's paper, illustrate his life experience in Mdo smad and introduce the legacy he left to his hometown. See Lobsang Yongdan, "The Invention of a Tibetan Lama General: a Biographical Account of Bla ma dkar po (1835-1895)," 67-92.

28 Skal bzang legs bshad, Rje btsun Byams pa mthu stobs Kun dga' rgyal mtshan gyi rnam thar (hereafter Rnam thar, Beijing: Zhongguo zangxue chubanshe, 1994), 249-268. Gannan zhou wenshi ziliao weiyuanhui, Rje btsun byams pa mthu stobs kun dga' rgyal mtshan dpal bzang po'i rnam thar nor bu'i 'khri shing las mdor bsdus khrigs chags su bsdebs pa bzhugs so (hereafter Rnam thar nor bu), 7-8; Lama garao buofo zhuanlïe, 4. This version of Bla ma dkar po's biography is extracted from Rnam thar, and trimmed by the wenshi ziliao committee. For a brief account on the Dbyi li tshang, see Danqu, Zhuoni zangchuan fojiao lishi wenhua (Lanzhou: Gansu minzu chubanshe, 2007), 197, 227. His source is from the co-authored book of Luosang Dunzhu and Bingjue Ciren, Anduo gucha chandingsi (Lanzhou: Gansu minzu chubanshe, 1995).

${ }^{29}$ Qingshilu (QSL), Xuanzong, j410.5a-7a; j414.2a; Wenzong, j142.13a-b; j154.6b. 
Khoja Wali Khan's attack of Kashgar 喀什 (1851) and the increasingly strong presence of the Russian Empire along the border, tensions were high among the Manchu officials, Mongols, Russians and Kazakhs in Dzungaria in the early 1850 s. Bla ma dkar po returned to Chone again for safety consideration. ${ }^{30}$

Neither the hagiography nor Chas pa oral history gives too much detail about his experience in Chone, where his reputation among Mongols could easily incur critics from the local sangha with respect to his poor monastic training. Bla ma dkar po tried to elevate his position in the monastic community, as his biography shows, by building personal connections with famous lamas in Mdo smad. The narrow path for him to elevate his religious status was through advanced training, which required a series of ordinations. ${ }^{31} \mathrm{He}$ managed to take the full vows of bhikkhu (dge slong) from the Second Tshe smon gling. Afterwards, he spent near ten years in Chone Monastery and a Chas pa hermitage, and joined Medical College (sman pa grwa tshang) of Labrang. He seemed to be uninterested in scholastic, philosophical or esoteric training. Whilst, he was incredibly sensitive to regional political circumstances. ${ }^{32}$

In 1862, the Old Teaching (Gedium, Ch. laojiao 老教) and New Teaching (Jahriyya, Ch. xinjiao 新教) Muslim groups clashed in Xunhua (Ya rdzi), a subprefecture to the north of Labrang. As the Qing officials juristically discriminated against the Jahriyya followers and suppressed them with a joint force of official troops, Tibetan cavalries and Chinese militias (Ch. mintuan 民團), the Salar 撒拉 and Huasi menbuan 華寺門宦 Muslims began to massacre their nonMuslim neighbors. Worse yet, the Shaanxi Hui revolt quickly spread to Gansu. Rumors poured into the Sino-Tibetan borderland and caused extreme social anxiety. The interethnic tension simmering in Minzhou 岷州 (Minxian 岷縣), Taozhou, Lintao 臨洮 (Didao 狄道) and Hezhou soon evolved into vengeful reciprocal massacres. Nonetheless, in Xinjiang, the three assaults of the Khoja Wali Khan against Kashgar were defeated by the Qing force. Bla ma dkar po thereupon took up a mission to seek patrons for Labrang in Dzungaria and departed for the seemingly peaceful Xinjiang on the third time. In late 1863, he arrived at Tarbagatai and ushered his spectacular military-

${ }^{30}$ For the Khoja Khan's invasion of Kashgar and the Qing vengeance, see James Millward, Eurasian Crossroads: A History of Xinjiang (London: Hurst \& Co, 2007), 115. Christian Tyler, Wild West China: The Taming of Xinjiang (London: Rutgers University Press, 2003), 68-9.

${ }^{31}$ In Dge lugs monasteries, the basic requirement of each stage of monastic training strictly corresponds to the specific stage of one's ordination.

32 In accordance with his letter, Lobsang Yongdan suggests that Bla ma dkar po was a good writer. See "The Invention of a Tibetan Lama General," 72. 
political ascendency along with the full eruption of the Dungan (HuiMuslim) Revolt. ${ }^{33}$

In 1864, Hui refugees who fled from Shaan-Gan brought Huielimination (Ch. miehui 滅回) stories to their Xinjiang compatriots. Many believed that the Qing court instructed Xinjiang officials to massacre Hui people as a precautionary measure. Their panic rapidly flared up revolts to forestall Qing garrisons across southern Xinjiang. Being provoked by the Islam-extermination (Ch. miejiao 滅教) tales, the Turkish-speaking Muslims of Kuqa 庫車, Urumqi 烏魯木齊, Aksu 阿克蘇, Kashgar and Yarkant 莎車 strengthened local Hui insurrections. Meanwhile, the situation in northern Xinjiang was at stake. On the excuse of the ineptitude of the Qing in suppressing rebellion and protecting foreign traders, a Russian force attacked the Qing army in Dzungaria, looted Tarbagatai and sequentially besieged Ili. When the Qing and Russian plenipotentiaries finalized the Treaty of Tarbagatai 塔城議定書, local Muslims were bracing for revolt. ${ }^{34}$

In the Chinese New Year of 1865, Tarbagatai Muslims killed the Manchu amban, looted the weapon depot and besieged the Qing garrison soldiers and non-Muslim civilians within the city. Witnessing ruinous battle scenes, Bla ma dkar po gave up the bhikkhu vows in front of the Maitreya statue at Zh'i ne yang Monastery (possibly a Chinese Buddhist temple) and organized a militia to counterattack the insurgents. Due to the long distance between Xinjiang and Beijing, the court confirmed the siege of Tarbagatai three months later. By then, Bla ma dkar po had raised the siege and rescued the garrison troop. Learning his success in battle, the emperor entitled him "bo thog thu." Considering the Qing force in Xinjiang almost collapsed, the court instructed him to command non-Muslim militias. The court may be unclear about the secular identity of Bla ma dkar po since the ho thug thu title was only granted to the most outstanding Tibetan and Mongolian reincarnate lamas. This unusual reward likely followed the precedent of the Dbyi li tshang, who shortly acted as the leading commander when the Ili general 伊犁將軍 died in the critical moment of the War of the Seven Khojas 七和卓之亂 three decades ago. ${ }^{35}$

\footnotetext{
33 Yang Yuxiu et al., Pinghui z̧hi (Guangxu jichou edition, 1889), j3, 1a-2b. QSL, Wenzong, j347.15a-b; Muzong, j16.11b-12b; for local officials" "faults", see j18.32a34 a.

${ }^{34}$ Skal bzang legs bshad, Rnam thar, 284-334. Ming Xu, “Zoubao hasake defang 奏 報哈薩克地方,” 4 June 1863, National Palace Museum (hereafter NPM), Taiwan, 090528; “Zhaolu ji eguo zhaohui kanding liangguo bianjie shi 照錄給俄國照會勘 定兩國邊界事,” 29 July 1863, NPM, 090228.

35 QSL, Muzong, j134.14a-b; Skal bzang legs bshad, Rnam thar 281-82; Rnam thar nor bu, 11-2; Lama garao buofo zhuanlüe, 7-8.
} 
However, the situation continuously deteriorated as Yaqub Beg (Agubai 阿古柏, 1820-77) unified the revolting forces in Khashgar, Khotan 和田 and Urumqi and established the emirate to replace the Qing control of Muslims in Xinjiang. In the second month of 1866, the Hui and Kazakh insurgents besieged Tarbagatai again. ${ }^{36}$ The remaining Qing troops and local militias in Ili and Tarbagatai withdrew to Uriankhai, Kobdo 科布多 and Uliyasutai 烏里雅蘇台, the only region in Xinjiang that was under the Qing control. The following years observed that Bla ma dkar po's influence on Mongols became irreplaceable. He was concerned with the conservative strategy adopted by Uliyasutai General and Temporary Ili General 署伊犁將 軍 Li Yunlin 李雲麟 (1834-97). The relationship between Bla ma dkar po and this Han Plain White Banner 漢軍正白旗 official worsened when they had divergent opinions over the recapture of northern Xinjiang, the reinforcement of Bayandai 巴顏岱, and the acceptance of Daur (Suolun 索倫), Sibe (Xibo 錫伯) and Kazakh refugees from the Russia occupied areas. After Bla ma dkar po accepted these refugees without any imperial permission, the Ili general reported in the fifth month of 1867 to the emperor that the bo thog thu had centralized power for his own sake. To weaken Bla ma dkar po, Li suggested endowing the lama with Eleuths (Oirats) 厄魯特 Mongols and instructing him to resettle the Eleuths and Torghut 土爾扈特 Mongols along the Irtysh River 額爾齊斯河, the Qing-Russian borderland. Ideally, the Mongols would form a defensive line between Russia and Uliyasutai. The emperor turned down Li's suggestion while assuring him that the employment of Bla ma dkar po was an expedient. $^{37}$

From 1868 to 1871, the ho thog thu's militia of several thousand horsemen was repeatedly recruited to the battlefields in Tarbagatai and Bayandai. He also fought against the Muslim insurgents in Uliyasutai and the mutinied Chinese garrison soldiers in Burultokai 布魯爾托海. The war seemed not to cease in a short time. To settle his nomadic followers and ensure them pasture to herd, Bla ma dkar po obtained an Uriankhai grassland from the Qing court in the name of building monasteries. In the 1870s, he restored two monasteries known as Bkra shis chos 'khor gling and Bshad grub dar rgyas gling, where were named as Chenghua si 承化寺 and Puqing si 普慶寺 respectively by the Tongzhi 同治 Emperor (1856-75) and the Guangxu 光緒 Emperor (1871-1908). He invited religious teachers from Labrang to establish complete monastic curriculums. As he became the most influential figure among Eleuths and Torghut Mongols as well as Daur

\footnotetext{
36 QSL, Muzong, j177.1b-3b.

${ }^{37}$ QSL, Muzong, j196.42a-b; j197.10b-12b; j201.9b-11b; j203.22a-b; j209.21a-22a.
} 
and Sibe refugees, he controlled a huge military force in Dzungaria. Xinjiang officials regarded him as a threat to Qing control of northern Xinjiang. Consequently, Bla ma dkar po confronted the escalating political exclusion of Manchu and Chinese authorities. His reputation soared but his political career went nowhere. ${ }^{38}$

Meanwhile, the Qing court preoccupied by the multifocal revolts across China proper finally arranged the expedition to recapture Xinjiang. By 1873, Zuo Zongtang 左宗棠 (1812-85) suppressed the Shaan-Gan Muslim revolts in multiple locales. Due to Russia reoccupied Ili and overtly penetrated into Tarbagatai and Altai, Zuo was concerned by the Russian Empire in the western borderland. He insisted on "inland frontier defense" (Ch. saifang 塞防) and debated with Li Hongzhang 李鴻章 (1823-1901) who tended to pour resources into "sea defense" (Ch. haifang 海防). Wining the court debate and gaining the support of the Empress Dowager Cixi 慈禧太 后 (1835-1908), Zuo directed the expeditionary force to pacify Xinjiang unrest in 1876. Bla ma dkar po was required to contribute provisions to the Qing army. His militia was dismissed for "wasting grains without merits" in the course of Zuo's campaign against the emirate of Yaqub Beg. After the Qing force seized Xinjiang by 1878, the lama general's political career and even personal safety faced more serious risk. Especially when the Qing government tackled the Russian occupation of Ili through diplomatic means, he was caught in the swirl of the Qing-Russian negotiation. ${ }^{39}$

In the midst of treaty negotiation with Russia to return Ili, the Russian government demanded the Qing representatives in Livadia to investigate a dusted incident. Two years ago, the Russian officer Potanin 坡塔甯 led an armed delegation to investigate the issue of Kazakh residents who fled from Russia to Altai. Because these Kazakhs were received by Bla ma dkar po, Potanin urged him to return the Russian residents. The delegation entered Chenghua si without dismounting from the horse in sign of respect. Such behavior was considered violating the basic etiquette to visit monastery. The offended disciples incited a fight. Two companions of Potanin were killed in a brief exchange of fire. Potanin was arrested and unarmed, then, expelled by Bla ma dkar po. Later, Tarbagatai Councilor Minister 參贊大臣 Yinglian 英廉 appointed the translator Bugai 布該 to assist

38 QSL, Muzong, j249.17b; j269.17a-19a; j232.19b-20b; j316.13a-14a; j348.12a13b; j366.24a-b.

39 Zuo Zongtang, Zuo wenxiang gong zoudu xubian (Guxiangge, 1902), j74.1a-4a; j75.1b-5b; j76.3b-6a, 8b-10a. For using Chenghua si as a case to examine the Qing politics in this period and the relation between the lama and Xinjiang officials, see Ma Yun, "Chenghua si sengzhong qianxi shulun," Journal of Xinjiang Normal University 29:3 (2008):26-9. 
Russian official Wulasufu 烏拉索付 (Vlasov?) to investigate the case. Wulasufu arrived at Chenghua si earlier than Bugai and experienced a similar hostile treatment. As the Qing was busy in seizing Xinjiang, the case was shelved. In 1878, Russian officials intended to use this incident to bargain for the best political and economic interests with the Qing government. The Russian government urged the Zongli Yamen 總理衙門 (Office in Charge of Affairs of All Nations) to investigate the case and punish the leader who insulted Russian officials and detained their weapons. ${ }^{40}$

The Qing court was quite cautious in dealing with this issue. As Xilun 錫綸 (d. 1886) was Bla ma dkar po's old acquaintance, the court appointed him as the new councilor minister of Tarbagatai to inquire into the case and seek a proper solution. The investigation was completed by the sixth month of 1878 . The case was clear from the Qing court's point of view. It was the fault of the "vulgar and reckless" Bla ma dkar po, whose well-known anti-Russian attitude and actions gave Russia a vantage point to bargain in the treaty negotiation. He should be better ousted from Xinjiang. However, it was a difficult matter for Xilun to handle, for, the lama was honored by several hundred thousand of Dzungaria inhabitants. To prevent the imperial opinion from causing estrangement and enmity among the lama's followers, Zuo Zongtang, Jinshun 金順 (1831-85) and Xilun came up with a sophisticated solution. They implicitly persuaded Bla ma dkar po to petition the emperor for permission to leave Xinjiang and offer tea in Tibet. In the eleventh month of 1879, the Guangxu Emperor granted the lama general a three-year leave to visit Lhasa. ${ }^{41}$

It seems that an exchange of political interests was involved as well. In 1866, the religious authorities of Chone and officials of the Tshe smon gling estate in Lhasa identified Ngag dbang blo bzang bstan pa'i rgyal mtshan (1861-1919), a five-year old boy from Zho tshang village near Chone town, as the Third Tshe smon gling. ${ }^{42}$ They petitioned the emperors time and again via the Lhasa amban and influential Ü-Tsang religious leaders for restoring the Tshe smon gling

${ }^{40}$ QSL, Dezong, j60.22a-23a.

${ }^{41}$ QSL, Dezong, j104.13a. For the imperial order to instruct Bla ma dkar po to offer tea in Tibet, see “Gunga Zhalecan fengzhi ruzang aocha 棍噶札勒參奉旨入藏謷 茶,” 1883, Qingdai gongzhong dang zouzhe ji junjichu dang zhe jian 清代宮中檔奏 摺及軍機處檔摺件，NPM，408010038. For a similar account in the lama's biography, see Skal bzang legs bshad, Rnam thar, 330. This record is not included in the shorter version of the biography.

42 The Second Tshe smon gling was prohibited from rebirth by the Qing government and his property was confiscated by the bKa 'shag in 1845. Utilizing the religious connection with Torghut princes, the Chone monastic authorities attempted to extricate the Second from custody, relocate him to Dzungaria and restore his position in 1860 . However, the lama passed away before making the move. 
lineage and his nominhan 諾門品status. Repeatedly declined by the Imperial Household Department 內務府 (dorgi yamen), they secretly enthroned Ngag dbang blo bzang at Chone Monastery. Since Bla ma dkar po was ordinated by the Second Tshe smon gling and cherished this momentous relationship defined by the sangha tradition, he coordinated a petition from Xinjiang in 1879. The imperial memorial of Jinshun and Xilun indicate that Torghut Mongol princes contributed 1,000 horses and requested an imperial permit for Ngag dbang blo bzang to study in Lhasa. Although a similar petition sent through Lhasa Amban Songgui 松溎 (1833-1907) was just turned down by the dorgi yamen, surprisingly, the request from Xinjiang was approved by the emperor. ${ }^{43}$

In 1881, Bla ma dkar po departed for Tibet with a huge fortune. He generously donated cash and religious objects to famous Buddhist sites along his slow pilgrimage journey en route to Lhasa from Lanzhou, Xi'an and Chengdu. He spent over 100,000 taels of silver on gilding the brass roof of an assembly hall and several hundred religious artifacts to Labrang Monastery. The story of his wealth had circulated among Lhasa residents before his arrival by the New Year of 1883. As he would deliver an imperial edict to the Dailai Lama on behalf of the emperor, the Bka' shag officials welcomed him with a high-standard protocol despite the fact that the basis for his official rank as ho thog thu was unclear. Having considerable political importance, Bla ma dkar po was immediately involved in Lhasa politics. ${ }^{44}$

In the second month, a quarrel between a Nepalese jewelry dealer and two Tibetan women evolved into a Tibetan riot against all Nepalese traders in Lhasa, ending up with the destruction of their stores. The traders requested for the intervention of the Gurkha army. When the Nepalese king planned for an attack, the Bka' shag authorities consulted Bla ma dkar po about a solution. Learning the traders' demand of economic compensation, he suggested to pay off the Nepalis and contributed his own silver. His biography indicates that the lama borrowed 80,000 taels from the Sichuan general governor to settle the incident, and clarified that the compensation was paid by those who damaged Nepalese stores. ${ }^{45}$ The Qing record suggests that the traders demanded for 183,000 taels. Sichuan Province paid 80,000 tales. ${ }^{46}$ To reward his contribution to the resolution of the Tibetan-

${ }^{43}$ QSL, Dezong, j206.6a.

${ }^{44}$ Skal bzang legs bshad, Rnam thar, 334-49.

${ }^{45}$ Skal bzang legs bshad, Rnam thar, 376-78; Rnam thar nor bu, 31-2; Lama garao buofo zhuanlïe, 23-5. For a more detailed record of this event, see the imperial memorial of Amban Selenge 色楞額 in Guangxu chao zhupi zouzhe vol.111 (Beijing: Zhonghua shuju, 1996), 404-5.

${ }^{46}$ QSL, Dezong, j186.13b-14a. 
Nepali dispute, the Guangxu Emperor bestowed him the title of Devout Chan Preceptor (Ch. duxin chanshi 篤信禪師). Around the same time, Bla ma dkar po met the Third Tshe smon gling Ngag dbang blo bzang in Lhasa. In the principle of exchanging favors, he urged the Bka' shag government to return the Second Tshe smon gling's estate to the successor, the future Dga' ldan khri pa and regent of Tibet. ${ }^{47}$

The pilgrimage of Bla ma dkar po was fruitful as well. The Rnam thar portrays him as a humble and devoted Buddhist. With the witness of the Thirteenth Dalai Lama (1876-1933), he took the bhikkhu vows and rejoined the monastic community. He patronized famous incarnations and reputable scholars, and even made the jeweled crown (jo bo o rgyan) to the precious statue of Jowo Shakyamuni at Jokhang Monastery. Yet, his stay in Lhasa was costly. He donated over 210,000 taels of silver in various occasions. A Lhasa complimentary saying highlights his presence in Central Tibet:

The 'Jam dbyangs bzhad pa satisfied Lhasans' need of dharma. The Khalkha Rje btsun dam pa satisfied Lhasans' need of silver. The Chone Nomen khan satisfied Lhasans' need of justice. Bla ma dkar po satisfied Lhasans' need of dharma, silver and justice. ${ }^{48}$

In 1885, the lama general left Lhasa and travelled across southern China to Beijing. He met provincial governors, powerful Chinese officials and eventually had an audience with the emperor in 1886. A clear image of the collapsing Qing Empire emerged in his vision. For almost two years, he visited the central yamens from one to another and waited endlessly for the imperial appointment. The court was unwilling to give Bla ma dkar po a formal official position in Xinjiang. His political status was not decided even when he was permitted to return to Dzungaria in 1888. Yet, the journey to Xinjiang was suspended for another year because of the British campaign on the southern border of Tibet. Two years previously, Sichuan Governor General Liu Bingzhang 劉秉璋 (1826-1905) and his predecessor Ding Baozhen 丁寶楨 (1820-86) had suggested the emperor to assign Bla ma dkar po to deal with the Tibetan-British issue. Now, the lama general was recommended to serve as the regent of Tibet. Nevertheless, on the basis of the imperial bureaucratic evaluation that lasted for several months, it was decided the bo thog thu was not qualified. The Zongli yamen officials asserted that he was reckless and war-oriented, and therefore could spark trouble in Tibet. In spring 1890, Bla ma dkar po embarked on a trip across China from end to

\footnotetext{
${ }^{47}$ Dung dkar blo bzang 'phrin las, Dung dkar tshig mdzod chen mo (Beijing: Zhongguo zangxue chubanshe, 2002), 1707-08.

${ }^{48}$ Rnam thar nor bu, 35-6; Lama garao buofo zhbuanlïe, 28.
} 
end. En route to Altai, he planned to return to the homeland that he had left nearly thirty years ago. ${ }^{49}$

\section{The Legacy of Bla ma dkar po}

At this point, Bla ma dkar po's economic wealth, political achievement and religious reputation were well known by fellowtownsmen and religious authorities in Mdo smad. In the fourth month of 1890, he arrived at Lanzhou, where two opposite attitudes awaited him. On the one hand, the Fourth 'Jam dbyangs bzhad pa Skal bzang thub bstan dbang phyug (1856-1916), an enthusiastic traveler and progressive leader who had rapidly expanded the ecclesiastical realm of Labrang, dispatched a huge escort cavalry to greet the lama general. On the other hand, the Eighteenth King Tshe dbang bsod nams stobs rgyal (Ch. Yang Zuolin 楊作霖, d. 1902) was the least interested in this religious figure. Bla ma dkar po was a mi ser in his Chas pa Banner, registered as a monk in one of the seventeen parish residences (khang tshan), and ordained at Chone Monastery. Expecting recognition from his home institute, the lama general declined Labrang's protocol escort. Instead of using the northern road from Lanzhou to Labrang via Hezhou, he took the southern route and returned to Chone via Minzhou, where the etiquette team of forty-eight banners customarily welcomed prestigious religious teachers to visit Chone. Nonetheless, he was disappointed again. Only the escort cavalry of Labrang was in Minzhou.

Bla ma dkar po abided by traditional norms to visit the Chone king. The politico-religious atmosphere was intense in Chone. In 1880, the Eighteenth King, a complete layman, obtained the ratification of senggang from the Qing government. His predecessor was the founder of several colleges and monasteries in Chone. In contrast to this established monastic scholar, the new mkhan po barely spoke Tibetan language. He was cultivated into a Confucian scholar-official. His pose writing shows a sophisticated Chinese taste. He favored Chinese culture but condemned Tibetan tradition. His enthronement thus was strongly opposed by the local sangha, which was reputed to value systematic training over fancy titles. Yet, Tshe dbang bsod nams inherited the position of abbot anyway, which caused the segregation of the ecclesiastic power at Chone Monastery. The seven major and ten minor reincarnations organized themselves into five factions. Inter-faction quarrels and feuds erupted frequently. Without any prestige in the monastic community, the king scarcely ran Senggang yamen and mediated conflicts. ${ }^{50}$ Therefore, Bla ma dkar po stayed

49 QSL, Dezong, j235.6b-7b; j240.13b; j.261.17a-b. Skal bzang legs bshad, Rnam thar, 348-60; 455-59.

50 Based on the conventional inheritance law, the king's elder son held the secular authority and his younger son joined Chone Monastery to become the mkhan po. See 
briefly at the yongs 'dus Palace. The king and religious authorities did not attach him enough importance. They treated him as a Chone lama working among the Dzungaria patrons of the Dbyi li tshang. They were unsatisfied with his association with the Jam dbyangs and his decision to transform Chenghua siand Puqing si in Xinjiang into the subordinate institutes of Labrang Monastery. Bla ma dkar po left Chone town for his tsho $b a$ with disappointment. In a causal conversation with his disciples later, he clearly belittled Chone as a small place without foresight and erudite people. He further commented that Chone Monastery had no well-educated lama to properly teach the king so that Tshe dbang bsod nams simply gave up learning Tibetan texts. ${ }^{51}$

In the six month of 1890 , Bla ma dkar po sojourned to Labrang and received a ceremonious welcome. The Fourth 'Jam dbyangs requested him to reside at Labrang and endowed him with a secondrank nang chen. Bla ma dkar po accepted the offer and sponsored the construction of a Shakyamuni hall. In the following year, the 'Jam dbyangs surveyed geomancy and chose a site inside the monastery to construct the residence for Bla ma dkar po. From the viewpoint of Labrang authorities, Bla ma dkar po studied in its Medical College, became a leading authority below the rank of the four gser khri lineages and naturally belonged to its monastic community. It was a de facto practice for some Chone monks to study at Labrang in this period. Although advanced monks of Chone traditionally pursued higher degrees in Lhasa, joining Labrang was an understandable personal choice. However, being a ho thog thu from the parish of Chone, Bla ma dkar po's choice inevitably created regional political consequences. Tension between Chone and Labrang had risen in the religious domain. $^{52}$

In years when Bla ma dkar po was away from Xinjiang, local officials considered the lama as a political opponent and strived for weakening his influence in the Altai region. They reported to the court that Bla ma dkar po's followers concentrated around Chenghua si would eventually be in conflict with local Kazakhs. The Uriankhai leaders intended to take back their grassland and expel the Tarbagatai nomads. This event coincided with the power struggle between the Ili general (Manchu) and the newly installed Xinjiang governor (Chinese) in the course of the establishment of Xinjiang Province in the late 1880s. The demarcation of the administrative boundaries in Ili and Tarbagatai also made the Qing implementation of many policies

Taozhou tingzhi, 910. For the details of the reincarnation lineages in Chone, see Luosang Dunzhu and Bingjue Ciren, Anduo gucha chandingsi.

51 Skal bzang legs bshad, Rnam thar, 649-54; Rnam thar nor bu, 107; Lama garao buofo z̧huanlïe, 81.

52 Zhazha, Labulengsi huofo shixi (Lanzhou: Gansu minzu chubanshe, 2000), 240-43. 
inefficient in northern Xinjiang. Hence, the Qing court designated him to resolve the brewing grassland dispute between the lama's Tarbagata followers and the Uriankhai and Kobdo Mongols and Kazakhs. In the ninth month of 1890, Bla ma dkar po left Gansu for Urumqi to carry on the imperial mission. He commanded Tarbagatai Mongols to be resettled. His monastery was relocated to Bayingou/Bayinggou 八音/ 英溝 that was subordinated to the Kharausu 庫爾喀喇烏蘇 Subprefecture. Bla ma dkar po lived among the Mongol patrons and followers as an eminent lama, a ritual master and a Buddhist teacher. ${ }^{53}$

In the sixth month of 1894, he departed for his new monastery in Chone, which was given the name Bkra shis chos 'khor gling by the Thirteenth Dalai Lama. He had first started planning for this monastery ten years earlier during his stay in Lhasa. At that time, his fellow townsman, a dge shes who studied in Lhasa, informed him that Chas pa Monastery built and expanded since the fifteenth century was burned to the ground by Hui insurgents in the 1860s. This monastery had belonged to the Chas pa monk preceptor vested by the Ming and Qing governments. As the Muslim revolt severely disrupted the society and economy in Chone like elsewhere, neither the preceptor nor the local tsho ba could afford to rebuild the monastery. The dge shes requested a donation from the ho thog thu, who immediately made the decision to sponsor the construction. Bla ma dkar po conducted a fasting ritual at Pha bong kha Hermitage and consulted the highest religious authorities in Lhasa about the location and building protocol in the spring of 1884. He envisioned it as a Dge lugs university with four colleges and complete training systems. The Dalai Lama and the Oracle Gnas chung chose a site on the geomantic map of Chas pa valley and suggested to build the Kālacakravajra College (sa ris grwa tshang) first. Later that year, Bla ma dkar po gave the certificate letter and the authenticating objects of the Dalai Lama and "greet three monasteries" to his elder brother Dkon mchog bstan 'dzin, and entrusted him with the task to construct the Kālacakravajra College. In Chas pa, local monastic representatives, elder councils, tsho ba headmen and two Labrang reincarnated lamas organized the communal meeting to decide the building materials and labor to be apportioned for each tsho ba. In the eighth month of 1885, Chas pa people started the construction..$^{54}$

When the ho thog thu traveled across China, he sent funds time and again to support the construction. However, a shortage of funds occurred in 1888. With the completion of Kālacakravajra College, he planned to unify all hermitages along Chas pa valley, and established the other three colleges. After this plan was revealed to the public, it

53 QSL, Dezong, j267.8a-9b. Skal bzang legs bshad, Rnam thar, 550-68.

${ }^{54}$ Rnam thar nor bu, 57-66; Lama garao buofo zhuanlïe, 47-53. 
was immediately challenged by tsho $b a$ leaders and local monks of different hermitages. Since Chas pa was located among three huge university monasteries, namely, Chone, Labrang and Lhamo, the necessity of a new central monastery was questionable. The villagers were also concerned that the plan would move their hereditary religious objects and monks the new monastery in the territory of Dgon pa tsho ba. The countless inter-tsho ba feuds and enduring mutual hostilities impeded the formation of a religious unity on such a scale. At this time, Bla ma dkar po could not secure a stable income in Beijing. Because the construction stopped, he requested the Qing royal family to offer alms by stating that the monastery under construction was for the celebration of the sixtieth birthday of the Empress Dowager Cixi. The emperor assigned Encheng 恩承 (1820-92) to inquiry into the matter. The investigation report from Taozhou confirmed that the monastery was being built in Chas pa Banner under the jurisdiction of Chone Chieftain Yang Zuolin. The ho thog thu thereby was bestowed with long-life tablets (Ch. changsheng painei 長生 牌位) of Guangxu and Cixi, a plaque with “Longevity Monastery” (Ch. wanshousi 萬壽寺) in the emperor's handwriting, and 7,000 taels of silver. The dissenting voices of some tsho ba were silenced. The project was carried on with the imperial funds flowing in. In the early 1890s, Bla ma dkar po also send the donations of the Mongol patrons back to hometown. By 1895, the construction of the exoteric, esoteric and medicine colleges were all completed. ${ }^{55}$

In the tenth month of 1894, the bo thog thu returned to Chone and waited at the newly established Bkra shis chos 'khor gling for the coming sixtieth birthday of Cixi. He held a huge ceremony for the Empress Dowager and performed Buddhist initiation rituals in the eleventh month. Afterwards, he fell ill and anticipated recovery. In the fifth month of 1895, the Qing court instructed him to return to Xinjiang. Coincidently, a sectarian conflict between the Yihewani and Khafiya orders led to a massive Muslim revolt in Xining and Hezhou. The Gansu-Xinjiang transportation was paralyzed. The Chinese, Tibetan and Muslim groups were coerced into revengeful killings again in Gansu and Qinghai. ${ }^{56}$ Bla ma dkar po waited for a clear situation. A month later, however, the emperor ordered him to handle the issue concerning British trade with Tibet. At this point, the Thirteenth Dalai Lama assumed complete ruling power. The enmity between the amban and the Bka' shag officials became irreconcilable. Lhasa authorities largely ignored the imperial instructions. As Qing China's sway over Tibet declined sharply, the court needed a reliable Tibetan middleman. The "recklessness" of the lama general seemed no longer relevant for

55 QSL, Dezong, j254.9b-10a. Rnam thar nor bu, 57-66; Lama garao huofo ₹huanlüe, 4753.

56 Jonathan Lipman, Familiar Strangers: A History of Muslims in Northwest China (Seattle: University of Washington Press, 1997), 142-54. 
the Qing government. From the seventh month to the tenth month, the Guangxu Emperor sent telegrams frequently to urge Bla ma dkar po to depart for Lhasa. The latter was prepared to make the long trek when his illness lightened. Unfortunately, his condition deteriorated again. He died on the thirtieth day of the tenth month, leaving behind the ho thog thu title, Bkra shis chos 'khor gling and a series of unsettled matters as his legacy. ${ }^{57}$

\section{Dilemma of the Chas pa Eighteen Tsho ba}

The Glu shod eight-tsho ba, A la five-shog $p a$ and Zam tsha six-tsho ba neighboring Chas pa were all subdued and donated to Lhamo Monastery (dga' ldan bshad sgrub pad dkar grol ba'i gling, Ch. Langmu si 郎 木寺) by the Chone kings in the eighteenth century. These tsho ba used to be a buffer zone between Chone and Labrang. From the early nineteenth century onward, Labrang swayed religious opinion and waged wars to integrate Tibetan tsho ba and federative units across Mdo smad. After Lhamo Monastery was incorporated into Labrang's primesubordinate monastic system, local tsho ba became the religious communities of Labrang Monastery. ${ }^{58}$ Hence, Chone and Labrang shared a jurisdictional border drawing from the Dme bo pasture to upper Klu chu valley. The borderline was superposed on many controversial territorial boundaries of the tsho ba separately ruled by Chone and Labrang. Owning to the seasonal mobility, land dispute and robbery/theft/raid practice of the pastoral and semi-sedentary tsho ba in this region, inter-tsho $b a$ feuds often broke out along the border. Peculiarly, no direct confrontation erupted between the two centers. As the Chone kings patronized every 'Jam dbyangs in the past two centuries, Chone yamen never meddled in local conflicts. In contrast to its aggressive incorporations elsewhere, Labrang also did not launch military campaign to capture the tsho ba along the outskirt of the Chone Kingdom. Most disputes were mediated by esteemed local leaders and lamas, and settled by involved tsho ba in accordance with traditional customs. $^{59}$

57 QSL, Dezong, j368.12b; j372.8b; j375.12a; j376.2b-3a. Skal bzang legs bshad, Rnam thar, 568-683; Rnam thar nor bu, 100-126; Lama garao buofo zhuanlüe, 76-103.

58 In 1747, the Chone king donated these tsho ba to the First Lha mo Gser khri rgyal mtshan seng ge (1678-1756) when he founded Stag tshang lha mo Monastery. See Grags pa mkhas grub, Khri thog Inga bou nga gsum pa khri chen rgyal mtshan seng ge'i rnam thar in Dga' Idan khri rabs rnam thar, 1-7b; Dkon mchog 'jigs med dbang po, Co ne'i bstan 'gyur gyi dkar chag yid bzhin nor bu'i phreng ba (Lanzhou: Lanzhou guji chubanshe, 1990), 233, 240; Mgon po dbang rgyal, Co ne sa skyong gi lo rgyus klu chu sngon mo'i gyer dbyangs ba (Lanzhou: Gansu minzu chubanshe, 1990), 43-6; Xiahe xianzhi (Lanzhou: Gansu wenhua chuabanshe, 1999), 38-54.

59 Ma and Wanma, Kan lho'i bod kyi tsho shog lo rgyus mdor bsdus, 120-24; Zhuoni xianzhi (Lanzhou: Gansu minzu chubanshe, 1994), 158-61. 
Yet, Labrang was the most attractive monastic university, pilgrim destination and market in the nineteenth century Mdo smad. By this time, the religious dominance of Chone had declined considerably. In the Chone-Labrang borderland, a shift of religious identity affiliation occurred among tsho $b a$ under the jurisdiction of the Chone king. Tibetan householders and communal monasteries in 'Brug chu, The bo, Gzhong pa and Chas pa preferred to send pupils and advanced students to Labrang. Conventionally, prospective Dge lugs students in the Chone Kingdom furthered their studies at Chone Monastery and obtained the highest Buddhist degrees at the central monastic universities in Lhasa. The Parish-Assembly Office and the seventeen parish residences managed pupil monks from different chos sde across the kingdom. As receiving ritual and scholastic trainings at which institute was a personal choice, the Chone Parish-Assembly Office did not interfere with the decision of local monks like Bla ma dkar po. Although Labrang absorbed Chone monks, it never announced any subordination of Chone communal monasteries. There was never a problem as long as Labrang did not designate abbots to manage religious affairs in Chone. However, the spectacular ascendency of Bla ma dkar po and the establishment of Bkra shis chos 'khor gling altered the policies of Chone and Labrang towards Chas pa. ${ }^{60}$

Within three decades, the lama general accumulated remarkable military merit, economic wealth, political power and religious capital. In 1865, the Qing government conferred the ho thog thu title on Bla ma dkar po for his defense of Tarbagatai. The title was designed by the Qing to be bestowed only on the highest rank Buddhist sprul sku. Being confused by the imperial award, Bla ma dkar po sent an attendant to consult Labrang authorities about the unprecedented case. The 'Jam dbyangs confirmed that Bla ma dkar po was a reincarnation of the sde srid Sangs rgyas rgya mtsho (1653-1705), the regent of the Fifth Dalai Lama (1617-82). Thereby, the Thorgut and Eleuth Mongols revered the lama general as a sprul sku. In tales about his life experience, the line between legends and believed facts is unclear. He is usually portrayed as a spiritual figure with supernatural power. Following his death, the Mongol followers requested the Qing to ratify the search of an incarnation in 1896. The Shan-Gan governor-general forwarded their petition to the emperor, who issued an edict that approved the lama to reincarnate as the ho thog thu of Chenghua si in Xinjiang. ${ }^{61}$ The Dalai Lama and the Panchen Lama performed rituals to supplicate an early rebirth of Bla ma dkar po and predicted that the birthplace would be in Mdo smad. In the process of legitimizing the reincarnate lineage,

${ }^{60}$ For the cases of changing religious identity affiliation in the Chone Kingdom, see Marnyi Gyatso, "Home on the Margins," 139-51, 184-94

61 The attendant was sent to Labrang from Xinjiang much later mainly because the Hui Mulism Revolt was fully repressed in Gansu in 1872. Skal bzang legs bshad, Rnam thar, 322. 
twenty-eight famous kings and saints were identified as the previous lives of Bla ma dkar po. Hence, as Lobsang Yongdan concludes, a sprul sku lineage was invented. ${ }^{62}$

A new spiritual lineage meant the inflow of political, religious and economic capitals and the reconfiguration of local human, material and immaterial resources. In such a border area, the situation was more complicated and sensitive. Chone authorities were long dissatisfied with the lama general for his generous donation of statues, silver, bronze roof and the construction cost of the Sakyamuni hall to Labrang while offering nothing to Chone. ${ }^{63}$ After all, he was from Chas $\mathrm{pa}$, a parish and a banner of Chone. Religious influence could easily turn into political power in the Tibetan areas. When Labrang led the construction of the new monastery in Chas pa, the lay and the ecclesiastic authorities in the Klu chu valley were alarmed. They were concerned with the interference of Labrang in all matters regarding Bla ma dkar po. Notwithstanding, the King Tshe dbang bsod nams could administer neither the reincarnation estates nor the Parish-Assembly Office. The brutality of factional feuds escalated time and again at Chone Monastery. The five factions also had no intention to contend with the issue and offend the Fourth 'Jam dbyangs. As a result, Chone authorities were discontented with Labrang while tolerating its religious infiltration. ${ }^{64}$

In 1895, the concealed Chone-Labrang friction evolved into a multifaceted contention. The lama general never explicitly indicated the ownership of Bkra shis chos 'khor gling. In an official meeting with the ho thog thu, Encheng asserted that the emperor sponsored the construction and the monastery belonged to the Great Qing. He instructed the lama to treat it as a project of the state, build an enormous compact of halls and temples, and recruit all yellow-hat monks of the region to recite sutras for the emperor and empress dowager. What was being articulated by Encheng was the bureaucratic and euphonic cliché, but it seems that Bla ma dkar po took these words seriously. He was inclined to create another regional university rather than a monastery affiliated to Chone or Labrang. ${ }^{.65}$

However, local reality was complex. Driven by intricate rationales, Chone authorities, Labrang Monastery and the Chas pa eighteen tsho ba all seized some space to interpret the status of Bkra shis chos 'khor gling. The eighteen tsho $b a$ and their Buddhist priests

${ }^{62}$ Lobsang Yongdan, "The Invention of a Tibetan Lama General," 87-9.

${ }^{63}$ Zhazha, Labulengsi huofo shixi, 240.

${ }^{64}$ David Ekvall, Outposts or Tibetan Border Sketches (New York: Alliance Press Co., 1907), 148-49.

${ }^{65}$ Skal bzang legs bshad, Rnam thar, 423-25. 
insisted that the monastery was their communal monastery. They contributed land, material and labor to build the monastery and dedicated it to the ho thog thu. The monastery was not a reconstruction of the old Chas pa dgon pa previously owned by the Chas pa senggang and subordinated to Chone Monastery. It was a regional Buddhist institute sponsored by the Qing emperor. For Labrang authorities, the ho thog thu was a second-rank reincarnation. The new monastery adopted the educational system, curriculums and monastic regulations of Labrang. It was established as a branch institute and managed by Labrang reincarnate lamas and religious teachers. Therefore, the 'Jam dbyangs assigned a dharma throne holder to Bkra shis chos 'khor gling after Bla ma dkar po passed away. ${ }^{66}$ The appointment of the kbri pa would transform the Chas pa eighteen tsho ba into a religiously affiliated community of Labrang, effectively dissociating them from the banner system of Chone. Chas pa monks and villagers welcomed the decision of Labrang. Because the Chone king fielded militia time and again to assist the Qing army to repress the Muslim revolts, the eighteen tsho ba like elsewhere in Chone, lost many fathers and sons in battle and suffered miserably in the aftermath of the war. They wished to exempt themselves from the militia corvée by altering the religious identity affiliation. ${ }^{67}$

The king and ecclesiastic authorities in Chone were alerted by the allied action of Chas pa Tibetans and Labrang leaders. The eighteen tsho ba were the subjects of the king and the chos sde of Chone Monastery, which granted the Senggang yamen unquestionable right to administer the communal monastery of Chas pa Banner as a subordinate institute. Moreover, the emperor granted an annual supply of 600 dan 石 of grain to Bkra shis chos 'khor gling from 1897 onward. Given that the grain was provided by Taozhou Subprefecture, the monastery became a registered monastery in Taozhou. It was a long tradition that Chone managed the Qing-vested Tibetan monasteries in Taozhou, not to mention that the dgon $p a$ was built by congregating the hermitages managed by Chone Monastery. Chone authorities believed that the Fourth 'Jam dbyangs broke the oral assent on politico-religious boundaries agreed by his predecessor and the sixteenth king in the 1840s. Even though the contemporary Chone king barely maintained the patron-priest relation with the Jam dbyangs lineage, Labrang authorities could not tread on this agreement and transgress the politico-religious border. Thus, the khri pa sent by Labrang retired from the contest. Chone appointed a throne holder straightaway in the

\footnotetext{
66 Zhazha, Jiayang butuketu shixi, 243.

67 QSL, Muzong, j109.25b-26a, j137.15b; j138.23a-b, j145.38a-40a, j153.8b-9a, j213.15a-16b; Pinghui zhi, j3.7a, 10a-b, 21a-b, 24a-b, 27b-28a, j4.2a; j5.7b, 21a; Zhang Yandu, Taozhou tingzhi, 985-86; Zhuoni wenshi ziliao, vol.7, 130.
} 
late 1890s, which provoked a decade long resistance by Bkra shis chos 'khor gling and the Chas pa tsho ba. ${ }^{68}$

The dispute was far from any foreseeable solution. Because the direct incorporation of Bkra shis chos 'khor gling was not an option, Labrang authorities tended to employ the Bla ma dkar po lineage to control the monastery and the eighteen tsho $b a$. Three years after the bo thog thu's funeral, the 'Jam dbyangs divined that the reincarnation was born in the Datong River valley. He urged the lama general's estate officials to seek the new reincarnation. In 1901, Skal bzang tshul khrims bstan pa'i rgyal mtshan (1896-1911) from Xining was recognized as the Second Bla ma dkar po and enthroned in Chone. However, the monks and Mongols in Tarbagatai learnt the news and requested the reincarnation to ascend the dharma throne at Chenghua si in accordance with the imperial edict. Urged by Gansu officials, the young sprul sku had to depart for Xinjiang in spite of Labrang's unwillingness to let him go. The influence of the imperial government was not absent from this frontier. Chas pa community and local monks could not count on Labrang to settle the case. They turned to Taozhou officials for help. Nonetheless, the Taozhou magistrate acquired plentiful gifts from the Chone king and dismissed the petition of the Chas pa eighteen tsho ba. ${ }^{69}$

Opportunity knocked for Bkra shis chos 'khor gling when the first Gospel Church was erected in Taozhou by 1905. In order to free themselves from the Chone rule, the eighteen tsho ba sought help from the Gospel missionaries. In the local context, these foreign priests were clearly respected by the king and Chinese officials. Chas pa monks reached out to the church. David Ekvall commented on this bold move with a boastful tone:

A bitter animosity has for years existed between the lamaseries of Chone and Cheh pah kuh [Chaspa valley], for the heads of the former insist on exercising temporal power over the latter, which is the smaller Gomba [dGon pa]. This feeling was intensified when Chone Gomba authorities attempted to appoint the religious heads of Cheh pah kuh Gomba. Such authority was stoutly denied and resisted, and rather than yield to numbers and monies influence, Cheh pah kuh appointed a delegation to wait upon the missionaries at Tao cheo [Taozhou], for the purpose of offering, with properly drawn up deeds, the lamasery and all the property connected with it, to the Fub yin Tang [Gospel Hall]. ${ }^{70}$

\footnotetext{
${ }^{68}$ David Ekvall, Outposts or Tibetan Border Sketches, 188-93.

${ }^{69}$ Robert Ekvall, Gateway to Tibet: The Kansu-Tibetan Border (Camp Hill, Pennsylvania: Christian Publications, Inc., 1938), 54; Howard Van Dyck, William Christie: Apostle to Tibet (Shelbyville: Bible \& literature Missionary Foundation, 1956), 64-7.

${ }^{70}$ David Ekvall, Outposts or Tibetan Border Sketches, 148-49.
} 
Nonetheless, Ekvall and his colleagues knew the covert wrestling between the two predominant Tibetan political powers in this new horizon of evangelism. Another intention of Chas pa monks was to disgust and threaten Chone Buddhist authorities, who were antagonistic to the church and its workers. As the Tibetan mission relied on the acquiescence of the Chone king and the 'Jam dbyangs, the missionaries could not risk their Tibetan outposts to help Chas pa Tibetans. They turned down the delegation's request despite it being a dreamy opportunity for them to set up a station in the Tibetan hinterland beyond the Gansu-Amdo border. ${ }^{71}$

The case remained unsettled until a new twist emerged in 1911. On the one hand, the Second Bla ma dkar po died of an unclear cause in Ili (a source indicates in Xining). ${ }^{72}$ Following another round of divination, the Fourth 'Jam dbyangs engaged in the search of the sprul sku again. In 1915, Skal bzang 'phrin las lhun 'grub chos kyi rgyal mtshan (1911-1954) from Gla le'u khog of Chone was identified as the Third Bla ma dkar po. By then, the Manchu Empire had come to an end. Seeing no obligation to abide an order of the former dynasty, the Chas pa eighteen tsho ba never let the ho thog thu return to Tarbagatai. Local tsho ba monastic leaders needed the incarnation to manage the precarious situation of the valley, which was still caught in the midst of a covert conflict between Chone and Labrang. They enthroned the Third Bla ma dkar po as a local sprul sku at Bkra shis chos 'khor gling, and immediately escorted him to study at Labrang Monastery. They appropriated the Bla ma dkar po lineage of Chenghua si and expected the new incarnation to bargain with Chone authorities in the future. ${ }^{73}$

On the other hand, the Chone King Tshe dbang bsod nams died without a male heir in 1902. Embracing the Chinese advisor's suggestion, he had utilized the Chinese inheritance rule and chose Blo bzang bstan 'dzin rnam rgyal 'phrin las rdo rje (Ch. Yang Jiqing 楊積 慶, 1889-1937) of the royal lineage's third branch to be his successor in both political and religious titles. O rgyan rnying ma (Ch. Yang Ying 楊英) of the fourth branch, who was the nephew of the previous king and the uncle of Blo bzang bstan 'dzin, was dissatisfied with this testament. Based on Tibetan inheritance rule, he was the rightful successor. Meanwhile, as the nineteenth king was still a child, Consort Yang, Tshe dbang bsod nams' wife from a wealthy Chinese gentry family in Lintao, acted as the regent of the kingdom. She trusted the Chinese advisor and restrained the political influence of Chone Monastery. Abiding the official instruction to protect missionaries, she

71 David Ekvall, Outposts or Tibetan Border Sketches, 149.

72 Danqu, Zhuoni zangcbuan fojiao lishi wenbua, 194; Lobsang Yongdan, "The Invention of a Tibetan Lama General," 89.

${ }^{73}$ Danqu, Zhuoni zangchuan fojiao lishi wenhua, 195. 
allowed the evangelists to establish a Gospel outpost at the foot of Chone Monastery in 1905. The consort infuriated religious leaders in Chone. Their divergence became so extreme that some monastic factions supported $\mathrm{O}$ rgyan rnying ma to seize the throne. ${ }^{74}$ The fourth branch thus provoked fights within the royal lineage and reported the arrogation of Blo bzang bstan 'dzin to Gansu officials. The report was ignored by the Taozhou magistrate who favored the first branch for gifts. After the Qing collapsed and the local official was displaced, O rgyan rnying ma requested the Republican government of Gansu to appoint him as the chieftain and depose his nephew in 1913. He went to Lanzhou and appealed for an investigation. Yet, his request was declined again. The provincial government did not wish to change the status quo and instigate chaos in the border region. ${ }^{75}$

Already preoccupied by the discord concerning a legitimate successor, Consort Yang and the adopted heir also encountered other internal challenges. Over two hundred tsho ba of the The bo Eighteen Banners often organized themselves into small looting parties to raid caravans, travelers and Chinese villages. When the White Wolf (Ch. Bailang 白狼) insurgents swept across Shann-Gan and devastated the Klu chu valley in 1914, the 'Brug chu Four Banners were also in trouble with Xigu 西固 officials and Western botanists. ${ }^{76}$ In 1915, The bo Tibetans clashed with the missionaries of the Christian and Missionary Alliance, China Inland Mission, Swedish Pentecostal and Assemblies of God at Ta rge dgon pa (Ch. Luba si錄巴寺). The king and his militia were preoccupied with these events, which often turned into external troubles and led to the interference of Chinese officials.

[Thus] in recent years the neighboring Chinese mandarins have been unmercifully bleeding the present chief of Chone, who is but an unprincipled boy. The constant troubles between Chinese and Tibetans give the former many occasions, when hard up for money, to supply themselves from this never-failing source, and a systematic method of squeezing, facilitated by means of intimidation, is the result. ${ }^{77}$

Hence, Chas pa Banner faced less strict control from Chone. Under the pressure of the Labrang reincarnations who closely worked with Bla ma dkar po, the khri pa assigned by Chone was elbowed out of

\footnotetext{
74 Robert Ekvall, Gateway to Tibet, 54; Dyck, William Christie, 64-7.

75 Zhuoni wenshi ziliao vol.4, 5; Taozhou tingzhi, 841; Yang Shihong, Zhuoni Yang tusi zhuanlüe, 82-8.

${ }^{76}$ For the activities of the White Wolves and local reactions in south Gansu, see Mu Shouqi, Gan qing ning shilïe (Lanzhou: Guji shudian, 1990), j28.23b-33b; Jonathan Lipman, "The Border World of Gansu, 1895-1935," PhD diss., (Stanford University, 1981), 191-203.

77 David Ekvall, Outposts or Tibetan Border Sketches, 125.
} 
Chas pa. Local monastic leaders even thwarted the banner-chief who was appointed by the king to collect tax. The Labrang regime slid into Chas pa valley again. The Fourth 'Jam dbyangs designated the second throne holder for a three-year term to Bkra shis chos 'khor gling. The eighteen tsho ba became de facto religious communities of Labrang. ${ }^{78}$

Coincidently, the Ma family warlords 馬家軍閥 dominated northwestern China at this point. To expand territory and increase revenue, they initiated the integration of Tibetan and Mongol areas in Gansu and Qinghai. After the Fourth 'Jam dbyangs passed away in 1916, a dispute between the Labrang Regent, who was the Third Dbal mang tshang (1854-1918), and Treasurer Li Zongzhe 李宗哲 gave Xining-based Muslim warlord Ma Qi 馬麒 (1869-1931) an excuse to seize this political center and regional market. His interference was strongly opposed by Labrang monks and the family of the Fifth 'Jam dbyangs 'Blo bzang 'jam dbyangs ye shes bstan pa'i rgyal mtshan (1916-47). Labrang authorities had been busy organizing a pan-Amdo Tibetan alliance to fight against Ma Qi for a decade. At the same time, Consort Yang transferred the official seals of the Chone chieftain and senggang to Blo bzang bstan 'dzin. In his early 20s, the nineteenth Chone potentate increasingly accumulated power to hold together the collapsing kingdom. The young ruler upgraded the cruel methods of punishment and intimidation to consolidate control over his subjects. He launched punitive campaigns against the disobedient tsho ba on the margins of his realm. The narrow Chone dungeon imprisoned Tibetans (including monks) who troubled the king by attempting to change religious affiliation. Prisoners were physically abused, sometimes crippled or beheaded. In doing so, he sustained considerable deterrence against troublesome tsho $b a$ and defecting monasteries. $^{79}$

The Fifth 'Jam dbyangs' family (also known as the Huang 黃 family) was from Kham and thus new to the region and unfamiliar with the intricate politico-religious relationship between Chone and Labrang. With the Labrang militias being vanquished by Muslim troops several times, the 'Jam dbyangs' family requested the Chone ruler for military support. Knowing the political circumstances on the Sino-Tibetan frontier very well, and because of the religious incursion of Labrang, the nineteenth king refused to assist Labrang. He treated Labrang as a rival and a powder keg. Nonetheless, he was expected to respect the patron-priest relationship between his lineage and the 'Jam dbyangs bzhas pa. Similar to the retreat of Labrang from Chas pa in

\footnotetext{
78 Dyck, William Christie, 90-5; Robert Ekvall, Gateway to Tibet, 58-66.

79 Miao Zishu, Labuleng si gaikuang (Lanzhou: Gansu minzu chubanshe, 1987), 1724, 139-41; Gannan wenshi ziliao xuanji vol.3, 9-12. Nietupski, Labrang Monastery, 174 82.
} 
the late 1890s, polite gesture was shown by the king in 1925 . When the Fifth 'Jam dbyangs' family was under the tight pursuit of Ma Qi, Blo bzang bstan 'dzin allowed them to take refuge in northern Chone. Yet, the king did not meet the 'Jam dbyangs in person nor offered further help. To avoid souring relations between Chone and the Ma family warlords, he deployed all yamen officials and local managers to arrest whoever among his subjects were fighting for Labrang. Peculiarly, the Chas pa eighteenth tsho ba who had strived for the exemption from militia corvée were conscripted by the banner-chief and local manager to stop any The bo Tibetans from joining the war. ${ }^{80}$

\section{Further Remark: Unsettling as a Solution}

To conclude, the ascendency of Bla ma dkar po created a hot spot of local politics. His legacy was a pool of resource for Labrang to continue its politico-religious expansion, for Chone to maintain the hereditary control of a banner, and for the Chas pa eighteen tsho ba to obtain better religious support and resist the military corvée. The situation showcases the ways in which local authority took shape, local politics functioned and local tsho ba navigated themselves. The development of this case was conditioned by the politico-religious structures of Chone and Labrang, the dynamics of the changing regional ruler-subject relations, and the ebb and flow of powers in northwestern China. In years when the kingdom was disturbed by internal and external unrests, Chas pa monks succeeded in warding off Chone religious authorities. When Labrang was invaded by Muslim troops, Chas pa Tibetans failed to avoid the king's recruitment although they had a Labrang khri pa in residence. When the eighteen tsho ba were caught between Chone and Labrang, they sought solution from external authorities. The Qing magistrates, Republican officials and missionaries, instead of being frontier passengers, were never absent from local politics in Mdo smad.

Even though the dispute remained unsettled, like many unsolved local dissensions, an expedient practice was carried on until it became a tradition-wise solution. It is hard to know whether Chone and Labrang reached any new agreement prior to the 1950s. Neither side ever raked up the issue of Chas pa valley. Although Labrang Monastery appointed dharma throne holder to Bkra shis chos 'khor gling and recognized it as a subordinated institute, it never openly claimed that Chas pa Banner was its chos sde. Meanwhile, Chone yamen kept levying tax and corvée on the Chas pa eighteen tsho ba. This arrangement seemingly conformed to the needs of Chone and Labrang. Perhaps it has also served the needs of these two communities to avoid any mention of their awkward relations during this period in local history.

${ }^{80}$ Li Zhenyi, Gannan juanz̧̧i (Hezuo: Gannan ribao, 1986), 139. 
Buddhist records, as usual, omitted the intertwined violent scenario, social-political struggle and long-lasting resentment in local society. Oral accounts, despite containing profound social and cultural meanings of the event, deep memory of the communal feeling, judgement based on the reinterpretation of the past, and justification of the present, often obscured and reconstructed the "historical fact." As a result, the contest has been concealed from the outside world. The eighteen tsho ba no longer regard it as a dispute. The latter generations have a new interpretation. Chas pa Tibetans nowadays assert with pride that they receive "Buddhist teachings from Labrang, political administration from Chone, and grain from Taozhou (chos 'go blab rang, srid 'go co ne, 'bru 'go the rgyu)."

\section{Works Cited}

Archives, National Palace Museum (NPM), Taiwan.

Brag dgon pa dkon mchog bstan pa rab rgyas. Mdo smad chos 'byung [The Religious and Political History of Mdo smad] (1864). Lanzhou, Kan su'u mi rigs dpe skrun khang, 1982.

Buffetrille, Katia. "Some Remarks on Mediums: The Case of the lha pa of the Musical Festival (Glu rol) of Sog ru (A mdo)." MongoloTibetica Pragensia 1, no.2 (2008): 13-66.

Chen Qingying ed. Zang₹u buluo zhidu yanjü 藏族部落制度研究 [A Study on the Tibetan Tribal System].Beijing: Zhongguo zangxue chubanshe, 2002.

Clarke, Graham. "Aspects of the Social Organisation of Tibetan Pastoral Communities." In Tibetan Studies, Proceedings of the $5^{\text {th }}$ Seminar of the International Association of Tibetan Studies 1989, 393411. Narita, Japan, 1992.

Danqu. Zhuoni zangchuan fojiao lishi wenhua 卓尼藏傳佛教歷史文化 [Zhuoni Tibetan Buddhist History and Culture].Lanzhou: Gansu minzu chubanshe, 2007.

Diyi lishi dang'an guan (The First Historical Archives). Guangxu chao zhupi zouzhe 光緒朝硃批奏摺 Palace Midrange Rescript Memorials of the Guangxu Reign].Beijing: Zhonghua shuju, 1996.

Dpal ldan bkra shis, and Kevin Stuart. "Perilous Novelties: The A-mdo Tibetan Klu-rol Festival in Gling-rgyal Village.” Anthropos 93 (1998): 25-79. 
Dung dkar blo bzang 'phrin las. Dung dkar tshig mdzod chen mo [Great Dictionary of the White Conch]. Beijing: Zhongguo zangxue chubanshe, 2002.

Dyck, Howard Van. William Christie: Apostle to Tibet. Shelbyville: Bible \& literature Missionary Foundation, 1956.

Ekvall, David. Outposts or Tibetan Border Sketches. New York, Alliance Press Co., 1907.

Ekvall, Robert. Cultural Relations on the Kansu-Tibetan Border. Chicago: University of Chicago Press, 1939.

- Gateway to Tibet: The Kansu-Tibetan Border. Camp Hill, Pennsylvania: Christian Publications, Inc., 1938.

Epstein, Lawrence and Peng Wenbin. "Ritual, Ethnicity and Generational Identity." In Buddhism in Contemporary Tibet: Religious Revival and Cultural Identity, edited by Melvyn Goldstein and Matthew Kapstein, 120-138. Berkeley: University of California Press, 1998.

Farrer, Reginald. On the Eaves of the World vol.1-2. London: Edward Arnold, 1916.

Gannan zhou wenshi ziliao weiyuanhui. Rje btsun byams pa mthu stobs kun dga' rgyal mtshan dpal baang po'i rnam thar nor bu'i 'khri shing las mdor bsdus khrigs chags su bsdebs pa bzhugs so [The Summary of the Precious Biography of the Venerable and Almighty Tutop Künga Gyeltsen] and Lama Garao Huofo Zhuanlïe 喇嘛噶繞活佛傳略 [A Short Biography of Lama Karpo], published as Gannan wenshi ziliao xuanji 甘南文史資料選輯 [A Selection of Gannan Historical Materials] vol.7. Hezuo: Gannan baoshe, 1990.

—. Gannan wenshi qiliao xuanji vol.3. Hezuo: Gannan baoshe, 1984.

Gong Jinghan. Xunbua tingzhi 循化廳志 [Xunhua Subprefecture Gazetteer] (1790s). Taipei: Chengwen chubanshe, 1968.

Grags pa mkhas grub. Khri thog Inga bou nga gsum pa khri chen rgyal mtshan seng ge'i rnam thar [The Biography of the Fifty-Third Ganden Tripa Gyeltsen Sengge]. In Dga' ldan khri rabs rnam thar [Biographies of Ganden Tripa]. Block printed edition, 1810. 
Hayes, Jack Patrick. A Change in Worlds on the Sino-Tibetan Borderlands: Politics, Economies, and Environments in Northern Sichuan. Lanham: Lexington Books, 2014.

Hille, Marie-Paule, Bianca Horlemann and Paul Nietupski eds. Muslims in Amdo Tibetan Society: Multidisciplinary Approaches. Lanham: Lexington Books, 2015.

Hermanns, Matthias. Die Nomaden von Tibet. Wien: Verlag Herold, 1949.

'Jam dbyangs 'jigs med dbang po. Co ne'i bstan 'gyur gyi dkar chag [A Catalogue of the Chone Tengyur] (1773). Lanzhou: Kan su'u mi rigs dpe skrun khang, 1990.

Kang Xiaofei, and Donald S. Sutton. Contesting the Yellow Dragon: Ethnicity, Religion, and the State in the Sino-Tibetan Borderland. Leiden, Boston: Brill, 2016.

Karmay, Samten. "The Social Organization of Ling and the Term phu nu in the Gesar Epic." Bulletin of the School of Oriental and African Studies 58, no.2 (1995): 303-313.

Langelaar, Reinier. "Historical and Social Organisation on the Eastern Tibetan Plateau: The Territorial Origins and Etymology of tshoba." Inner Asia 21 (2019): 7-37.

—. "Descent and Houses in Rebgong (Reb gong): Group Formation and Rules of Recruitment among Eastern Tibetan tsho ba." In Mapping Amdo: Dynamics of Change, edited by Jarmila Ptáčková and Adrian Zens, 155-183. Prague: Oriental Institute CAS, 2017.

Levine, Nancy. "From Nomads to Ranchers: Managing Pasture Among Ethnic Tibetans in Sichuan." In Development, Society, and Environment in Tibet. Papers Presented at a Panel of the 7th Seminar of the International Association for Tibetan Studies, Graz 1995, edited by Graham Clarke, 69-76. Vienna: Verlag der Österreichischen Akademie der Wissenschaften, 1998.

Lévi-Strauss, Claude. The Way of the Masks. Translated by Sylvia Modelski. Seattle: University of Washington Press, 1982.

Li Anzhai. History of Tibetan Religion: A Study in the Field. Translated by Chie Nakane. Tokyo: Institute of Oriental Culture, The University of Tokyo, 1982. 
Li Zhenyi. Gannan jäaņ̧i 甘南簡史 [Gannan Brief History]. Hezuo: Gannan ribao, 1986.

Lipman, Jonathan. Familiar Strangers: A History of Muslims in Northwest China. Seattle: University of Washington Press, 1997.

—. “The Border World of Gansu, 1895-1935.” PhD diss. Stanford University, 1981.

Lobsang Yongdan. "The Invention of a Tibetan Lama General: a Biographical Account of Bla ma dkar po (1835-1895).” Revue d'Etudes Tibétaines 49 (2019): 67-92.

Luosang Dunzhu, and Bingjue Ciren. Anduo gucha chandingsi 安多古刹 禪定寺 [Amdo Ancient Monastery Chandingsi]. Lanzhou: Gansu minzu chubanshe, 1995.

Ma Dengkun, and Wanma Duoji, Kan lho'i bod kyi tsho shog lo rgyus mdor bsdus (Gannan zangzu buluo gaishu 甘南藏族部落概述) [An Overview of Gannan Tibetan Tribes]. Hezuo: Gannan baoshe, 1994.

Ma Yun, “Chenghua si sengzhong qianxi shulun 承化寺僧眾遷徙述 論 [An Analysis of the Relocation of Chenghua si Monks and Followers]." Journal of Xinjiang Normal University 29:3 (2008):26-9.

Marnyi Gyatso. "Home on the Margins: Tsho ba Societies of the Chone Kingdom on the Sino-Tibetan Frontier, 1862-1952." PhD diss. The Chinese University of Hong Kong, 2020.

—. "The Ming, Tibetan and Mongol Interactions in Shaping the Ming Fortification, Multicultural Society and Natural Landscape in Mdo smad, 1368-1644.” Revue d'Etudes Tibétaines 55 (2020): 351384.

Mgon po dbang rgyal. Co ne sa skyong gi lo rgyus klu chu sngon mo’i gyer dbyangs [A General History of the Chone Rulers]. Lanzhou: Kan su'u mi rigs dpe skrun khang, 1997.

Miao Zishu. Labuleng si gaikuang 拉卜楞寺概況 [The Basic Information of Labrang Monastery].Lanzhou: Gansu minzu chubanshe, 1987.

Millward, James A. Eurasian Crossroads: A History of Xinjiang. London: Hurst \& Co, 2007. 
Mu Shouqi. Gan ning qing shilïe 甘寧青史略 [The Essential History of Gansu, Ningxia,and Qinghai]. Lanzhou: Guji shudian, 1990.

Nietupski, Paul. Labrang Monastery: A Tibetan Buddhist Community on the Inner Asian Borderlands, 1709-1958. Lanham: Lexington Books, 2012.

Pirie, Fernanda. "Feuding, Mediation and the Negotiation of Authority Among the Nomads of Eastern Tibet." Max Planck Institute for Social Anthropology Working Paper 72 (2005): 1-30.

Qingshilu 清實錄 [The Qing Veritable Records]. Taipei: Taiwan zhongyang lishi yuyan yanjiusuo.

Rock, Joseph. The Amney Ma-Chben Range and Adjacent Regions: A Monographic Study. Roma: Instituto Italiano per il Medio ed Estremo Oriente, Serie Orientale Roma XII, 1956.

Samuel, Geoffrey. Civilized Shamans: Buddhism in Tibetan Societies. Washington and London: Smithsonian Institution Press, 1993.

Skal bzang legs bshad. Rje btsun byams pa mthu stobs kun dga' rgyal mtshan gyi mam thar [The Life-Story of Jétsün Jampa Tutop Künga Gyeltsen]. Beijing: Zhongguo zangxue chubanshe, 1994.

Stobs stag lha. "A Multi-Ethnic Village in Northeast Tibet: History, Ritual, and Daily Life in Chu cha." Asian Highlands Perspectives 24 (2013): 1-130.

Stübel, Hans. The Mewu Fantru: A Tibetan Tribe of Kansu. New Haven: HRAF Press, 1958.

Teichman, Eric. Travels of a Consular Officer in North-West China. Cambridge: Cambridge University Press, 1921.

Tuttle, Gray. "Pattern Recognition: Tracking the Spread of the Incarnation Institution through Time and across Tibetan Territory." In Revue d'Etudes Tibétaines, 38 (2017): 29-64.

—. "An Overview of Amdo (Northeastern Tibet) Historical Polities." https://collab.its.virginia.edu/wiki/aboutthl/An\%20Overview $\% 20$ of $\% 20$ Amdo $\% 20 \% 28$ Northeastern $\% 20$ Tibet $\% 29 \% 20$ Histo rical\%20Polities.html (Accessed 20 October 2019).

Tyler, Christian. Wild West China: The Taming of Xinjiang. London: Rutgers University Press, 2003. 
Xiahe Xianzhi bianzuan weiyuanhui. Xiahe xianzhi 夏河縣志 [Xiahe County Gazetteer]. Lanzhou: Gansu wenhua chuabanshe, 1999.

Yang Shihong. Zhuoni yang tusi zhuanlüe 卓尼楊土司傳略 [A Brief Biography of the Yang Chieftains]. Chengdu: Sichuan minzu chubanshe, 1989.

Yang Yuxiu, Wang Zhiyi, Zhang Rongze and Yang Cunze. Pinghui z̧hi 平回志 [Record of the Pacification of Hui]. Guangxu jichou edition, 1889.

Yeh, Emily. "Tibetan Range Wars: Spatial Politics and Authority on the Grasslands of Amdo." Development and Change 34, no.3 (2003): 499-523.

Yudru Tsomu. The Rise of Gönpo Namgyel in Kham: The Blind Warrior of Nyarong. New York, London: Lexington Books, 2015.

Zhazha. Labulengsi huofo shixi 拉卜楞寺活佛世系 [The Genealogies of the Incarnations in Labrang Monastery]. Lanzhou: Gansu minzu chubanshe, 2000.

Zhang Yandu. Taozhou tingzhi 洮州廳志 [Taozhou Subprefectural Gazetteer] (1907). Taipei: Chengwen chubanshe, 1970.

Zhouta ('Brug thar). Mdo smad rma khug tsha 'gram rong 'brog yul gru'i sngon byung mes po'i ngag gi lo rgyus deb ther chen mo zhes bya ba bzhugs so [The Great Annals of the Mdo smad Agricultural and Nomadic Districts]. Pe cing: Mi rigs dpe skrun khang, 2005.

一. Gannan zangzu buluo shebui lishi yu wenhua yanjiu 甘南藏族部落社 會歷史與文化研究 [A Study on the Gannan Tibetan Tribal Society and Culture]. Beijing: Zhongguo zangxue chubanshe, 2013.

Zhuoni xianzhi bianzuan weiyuanhui ed. Zhuoni xianzhi 卓尼縣志 [Zhuoni County Gazetteer]. Lanzhou: Gansu minzu chubanshe, 1994.

Zhuoni xian wenshi ziliao weiyuan hui ed. Zhuoni wenshi qiliao 卓尼文 史資料 [Zhuoni Historical Materials] vols.1-7. Zhuoni, 19842003. 
Zuo Zongtang. Zuo wenxiang gong roudu xubian 左文襄公奏牘續編 [The Continuation of Zuo Wengxiang gong's Imperial Memorials]. Guxiangge, 190 